\title{
Environmental policy analysis
}

- Dealing with economic distortions 

Uli norden 



\section{Environmental policy analysis \\ - Dealing with economic distortions}

Helge Sigurd Næss-Schmidt and Lars Jensen

TemaNord 2015:576 
Environmental policy analysis

- Dealing with economic distortions

Helge Sigurd Næss-Schmidt and Lars Jensen

ISBN 978-92-893-4393-0 (PRINT)

ISBN 978-92-893-4391-6 (PDF)

ISBN 978-92-893-4390-9 (EPUB)

http://dx.doi.org/10.6027/TN2015-576

TemaNord 2015:576

ISSN 0908-6692

(C) Nordic Council of Ministers 2015

Layout: Hanne Lebech

Cover photo: Imageselect

Print: Rosendahls-Schultz Grafisk

Printed in Denmark

This publication has been published with financial support by the Nordic Council of Ministers. However, the contents of this publication do not necessarily reflect the views, policies or recommendations of the Nordic Council of Ministers.

\section{www.norden.org/nordpub}

\section{Nordic co-operation}

Nordic co-operation is one of the world's most extensive forms of regional collaboration, involving Denmark, Finland, Iceland, Norway, Sweden, and the Faroe Islands, Greenland, and Åland.

Nordic co-operation has firm traditions in politics, the economy, and culture. It plays an important role in European and international collaboration, and aims at creating a strong Nordic community in a strong Europe.

Nordic co-operation seeks to safeguard Nordic and regional interests and principles in the global community. Common Nordic values help the region solidify its position as one of the world's most innovative and competitive.

\section{Nordic Council of Ministers}

Ved Stranden 18

DK-1061 Copenhagen $\mathrm{K}$

Phone (+45) 33960200

www.norden.org 


\section{Contents}

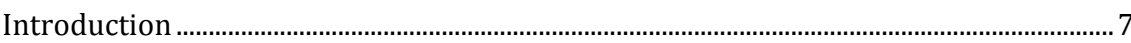

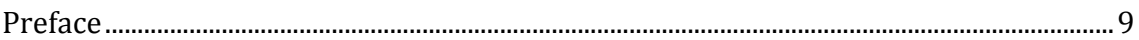

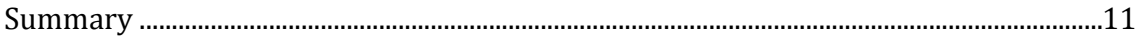

Scope of the study

Key lessons......................................................................................................................12

Current practices in the Nordic countries ..............................................................14

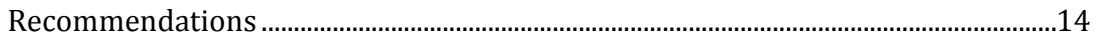

1. Dealing with distortions...........................................................................................15

1.1 A primer on labour market distortions ............................................................15

1.2 Marginal cost of public funds..........................................................................19

1.3 Assessing product market distortions...............................................................21

1.4 Distortions related to typical policy instrument categories...........................25

1.5 How distortions are dealt with in existing guidelines ...................................29

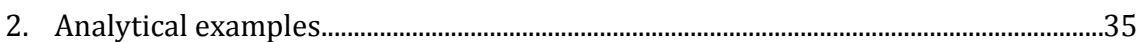

2.1 Example 1: Removing the PSO-tax on the market for electricity …................36

2.2 Example 2: A gradual mandatory scrap scheme for old wood

burning stoves ......................................................................................................4

2.3 Example 3: Car taxation ...............................................................................

2.4 Example 4: Waste management - higher recycling ……................................59

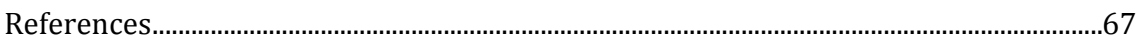

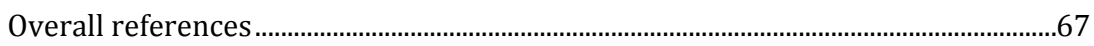

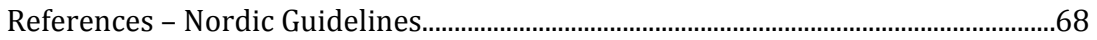

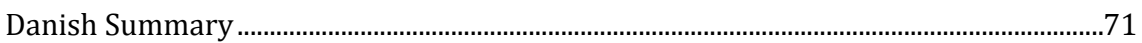

Studiets afgrænsning ............................................................................................

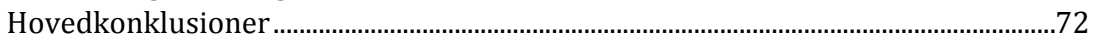

Nuværende praksis i de nordiske lande ..................................................................

Anbefalinger ....................................................................................................................

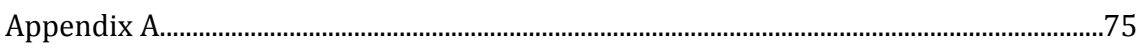

Analytical example 1 - removing the PSO-charge.......................................................75 



\section{Introduction}

Economic analysis in general and cost-benefit analysis in particular support the development of cost-efficient environmental policies in all Nordic countries. There exist available tools and guidelines for the different steps in such analysis. In this project The Working Group on Environment and Economy under the Nordic Council of Ministers (MEG) focus on possible distortions that policy instruments may cause on product and labour market respectively, and argue that these effects are important and should be included more frequently in ex-ante costbenefit analysis. Furthermore this is particularly true when several interventions already exist in the market, which is commonly the case when creating new policy instruments. The report explains, theoretically as well as by using practical examples, why and how including product and labour market distortions lead to better informed decision making.

Copenhagen Economics was chosen to write the report. The authors are responsible for the content as well as the recommendations which do not necessarily reflect the views and positions of the governments in the Nordic countries.

October 2015

Fredrik Granath

Chairman of the Working Group on

Environment and Economy under the

Nordic Council of Ministers 



\section{Preface}

Environmental policies justifiably form a substantial part of government policies in all Nordic countries. A wide range of policy instruments are used simultaneously and with substantial interactions - e.g. taxes on polluting activities, subsidies to support "cleaner" solutions and regulatory minimum standards. These instruments affect the functioning of both product and labour markets.

In this project, we highlight a number of issues arising when applying cost-benefit analysis to environmental policies, including how these issues are dealt with in the Nordic country guidelines. We will mainly focus on aspects related to distortions to product and labour markets, including e.g. the value of correcting externalities and the interplay between product market distortions through taxation and labour market distortions through implied public revenue consequences.

We will underpin the methodological issues by four analytical examples that show how applied cost-benefit analysis can be used to gauge the net impact of such policies. One example deals with car taxation, one with taxes on energy, one with a mandatory scrap scheme and one with waste treatment. The analytical examples are selected with a view to capturing potential complexities and important issues when dealing with distortions, and are of special relevance to the Nordic countries.

Practice shows that the evaluation of such policies is a challenge for member states, partly because present guidelines sometimes are not sufficiently easy to understand and apply for practitioners outside central economic ministries, and even there consistency is sometimes lacking.

Moreover, the parameters and precise implications of cost-benefit analysis can have a substantial impact on how different policy proposals come out in terms of net value and internal ranking. An illustration of these problems coupled with analytical examples can help create a better understanding of how such instruments can and should be used, as well as highlight a number of critical issues. 



\section{Summary}

\section{Scope of the study}

The Nordic countries have ambitious goals to encourage environmental policy objectives in a broad range of areas.

To ensure cost-effective policies, all Nordic countries are using costbenefit analysis. The goal is to support a policy making process where any given objective is achieved at the lowest costs and where, ideally, the marginal costs of obtaining the object equal the marginal benefits. This requires by definition a set of principles and practices that define how to calculate costs and benefits.

The aim of this study is to adress the cost-side of cost-benefit analysis, with a focus on the two main distortions that environmental policies can give rise to, and which cost-benefit analysis can help measure the size of.

The first is product market distortions. Almost by definition, environmental policies will create a wedge between the costs of producing the products that consumers want to buy and the market price that they will have to pay. This generates a welfare loss because consumers now buy less of the product at a higher price than the actual production costs. This is the so-called consumer loss effect.

The second is the possible distortion to the labour market. We take it as a given that the purpose of environmental policies is the environment, but what could be side effects on the labour market? Policy interventions will tend to reduce both productivity and real wages by making final goods more expensive: sounder environmental practices may e.g. require more costly treatment of waste or investments in energy efficiency which are not fully compensated in lower net costs to consumers. Policies may also directly or indirectly affect public finances: new environmental taxes increase revenues that can be used to reduce direct taxes on earned income. How do reduced real wages and such twists in the tax structure affect labour supply?

The study presents some key lessons from best practice in how to evaluate and calculate these two elements of possible distortions and compare it against actual practices as formulated in the existing Nordic guidelines. 


\section{Key lessons}

The standard practice when calculating product market distortions in empirical studies is relatively straightforward and based on the so-called consumer loss principle. We need to define the real underlying consumer market that is ultimately impacted by the environmental measure. For example, a measure that prohibits certain toxic substances used in the process of manufacturing will ultimately lead to an increase in the price of products using the substance. This leads to two types of losses: the higher production costs is one-to-one translated into a consumer loss. Then consumers will also cut back on demand because prices go up. At the margin, consumers are paying more for, and spending less on, the underlying goods than it costs to produce them in the cheapest possible way. So, we need to identify the market affected, the eventual direct increase in production costs and the change in demand from consumers.

A tax on a polluting activity acts in a similar, but not completely same, manner. The higher tax will translate into a higher price for consumers, inducing them to spend less. This is a loss to society because consumers willingness to pay is higher than the cost of producing the good.

What is important when doing these calculations is to understand that the additional consumer loss/gain from any incremental new policy initiative is highly dependent on the initial consumer loss created by the stock of existing regulation affecting the regulated activity.

A practical example from our report illustrates this point. The taxation of car use is in all Nordic countries substantial, creating large consumer losses, leaving aside the environmental objectives that the taxes are also meant to deliver on. This implies that consumers willingness to pay for car services (ownership and use of car) is already far above production costs. When adding another layer of taxation, the consumer loss will be much larger than if car use at the outset had been taxed at the same level as other goods.

Using best practice, calculation of labour market effects from product market interventions such as environmental policies should be build on four key labour market and public finance principles:

- Four dimensions of labour supply: clarify that labour supply decisions is not just about chosing between real leisure and paid work. As important are two other key "time uses", namely Do-It-Yourself work and black economy activities, neither of which are taxed. 
- Balanced budget approach: disregard effects of environmental policies which implicitly assume that they affect the long-term debt position of government.

- Unchanged income distribution: The purpose of environmental policies is to achieve environmental goals and not to change the income distribution. In combination with the balanced budget approach principle, this implies that effects on labour markets should be based on the principle that the net budget position and the distribution of income is unchanged.

- Zero long-run real wage elasticity of labour supply: environmental policies that affect the overall productivity of the economy e.g. command and control policies which makes production more costly, will as a first approximation not affect long-term labour supply (but may imply transitional costs as jobs lost in the impacted industry need to be recreated elsewhere).

The upshot of these four principles is first of all the following:

No double-dividend effects in general: higher income from environmental taxes should be recycled in a manner that keeps the distribution of income unchanged. This would in general imply that the marginal taxation of work and hence incentive to avoid taxed work would remain unchanged. We discuss variants of this principle in the report.

Policies that imply a net burden on public finances such as subsidies to new and greener technologies will have to be financed by higher tax rates. Even if the tax increase is designed so as to keep the income distribution unchanged, taking into account the joint effects of cheaper technology and higher taxes, the higher tax rate implies that incentives to shift time use into non-taxed activities will rise. We take it as given that access to the benefits of the new technology is not strictly dependent on the number of hours worked or the size of taxation income.

In turn, this implies that the new policy has derived consequences for the labour market in terms of reduced labour supply, even in the case where the joint effect of the technology support and higher tax leaves real wages unchanged. This is often called the Marginal Cost of Public Funds (MCPF) effect. 


\section{Current practices in the Nordic countries}

Clear guidelines on how to calculate product and labour market distortions in the Nordic countries are relatively sparse in general.

Most precisely incorporated in guidelines for Denmark, Norway and Sweden is the concept of Marginal Cost of Public Funds related to the need for increasing income taxation as recommended in standard costbenefit analysis (broadly in the same manner with deviations discussed in the report).

Despite the concept of consumer surplus/welfare being pretty standard in textbook economics and relatively simple to calculate once data exists, only few general recommendations on how to calculate consumer gains or losses can be found in guidelines. Neither have we seen evidence for the use of such estimates in actual applied cost-benefit analysis.

\section{Recommendations}

The lack of a rigourous approach when calculating product and labour market effects in environmental policies may reduce the quality of policy making. Obviously, it may lead to too optimistic assessments of net benefits to society of any given policy measure as important costs are not included. But, just as importantly, it may affect the ranking of a given set of policies aiming to achieve the same objective. Policies may all deliver on the environmental goal but differ significantly on their effects on labour and product markets, which should arguably be part of the decision-making process.

We thus recommend that the Nordic countries either individually or collectively establish some common guidelines on how to include such effects in their national policy design process. The compliance costs of incorporating such effects in cost-benefit analysis should not be exagerated. Key inputs to calculations such as the effects of the measure on the polluting activity, key product markets, and on public finances are typically already measured. 


\section{Dealing with distortions}

The purpose of this chapter is both to provide some general advice on how to assess economic distortions in in the context of cost-benefit (CB) analysis of a broad range of environmental policy measures, and compare that with current practices in the Nordic countries. We focus on the cost-side of CB-analysis, in particular the possible distortions to the functioning of the product and labour market as a consequence of changes in tax rates and revenues, and the potential losses consumers may experience as policy interventions affect the structure of their spending, i.e. shifting demand towards more environmentally sustainable practices.

We start by introducing the reader to a primer on labour market distortions and a discussion of the key relevant labour supply decisions in section 1.1. In section 1.2, we link such labour market effects to the concept of Marginal Cost of Public Funds (MCPF), which includes the distortionary costs from tax financing. In section 1.3, we discuss how policymakers should deal with product market distortions in intervention markets. In section 1.4, we list and discuss how a number of typical environmental policy measures are associated with product and/or labour market distortions. Finally, section 1.5 compares the existing Nordic guideline recommendations on how to deal with economic distortions.

\subsection{A primer on labour market distortions}

The key issue we raise in the context of distortions to labour supply resulting from environmental measures is how these measures impact the potential work force in terms of what they spend their time on, and how these choices affect public revenues (and productivity). Indeed, as will follow from our examples a very substantial part of policy interventions affect either directly or indirectly public revenues. Hence, tracking the links between environmental policy, public revenues and labour supply are important.

A number of key assumptions formulated in the literature lay the foundation for our suggestion of four key principles the policymaker 
should consider the implications of when evaluating potential distortionary impacts from policy interventions.

\subsubsection{I - Four dimensions of labour supply}

We suggest in line with the literature on labour supply that all persons essentially chose to split their time between four different activities of which only one is fully taxed: 1

- Pure leisure (including sleep): not taxed.

- Do-it-yourself work (DIY): not taxed.

- Black economy activites: work should be declared but is not, so no tax is paid, i.e. tax evasion.

- Regular work for a registred enterprise etc: taxed in principle, but remuneration may include none or low tax fringe benefits.

Thus, we are looking at a menu of options and not just a choice between formal paid work versus leisure. Only one of these activities is taxed both from a legal and practical perspective, and even here partial avoidance is possible through fringe benefits.

\subsubsection{II - Balanced budget approach}

Apply as a basic rule that we consider an ex-post balanced public budget, so that any measures that increase/reduce revenue should be neutralised by measures that reduce/increase revenue. In other words, when evaluating the effects of environmental policies we should ignore any effects that effectively arise from changes in net government fiscal positions. This is also the standard principle in guidelines.

\subsubsection{III - Unchanged income distribution}

When considering the overall labour market effect of a policy primarily meant to deliver on environmental issues, we suggest that policymakers assume an overall policy package that keeps the income distribution neutral. ${ }^{2}$ This will make the analysis easier as it is possible to leave out any impacts on labour supply from the redistribution of income, unless

\footnotetext{
See e.g. Copenhagen Economics (2014) and Rogerson (2008)

${ }^{2}$ See e.g. Copenhagen Economics (2014), Kaplow (2011) and Kaplow (2012).
} 
this is a specific policy objective in which case it should be a central part of the analysis, see e.g. explanation in section 1.4.

So, as an evaluation metric we should review labour market consequences of environmental policies in terms of a package that keeps unchanged both the budget balance over time and the income distribution.

\subsubsection{IV - Zero long-run real wage elasticity of labour supply}

One stylised feature of the labour market is a long-run real wage elasticity of labour supply of zero. ${ }^{3}$ This is the result of two factors working in opposite directions. When real wages go up, it becomes more expensive to spend time as leisure (the opportunity cost of leisure increases) and this increases labour supply - the substitution effect. However, at the same time, higher real wages also means higher real incomes, implying that workers can afford more leisure - the income effect.

\subsubsection{Use of the four principles in two examples}

The joint importance of the four steps above is elaborated by two examples.

\section{Example one}

A government-funded programme manages to increase productivity for all in society by $1 \%$ all incomes - wages, transfers, profits - increase by exactly $1 \%$ :

- Disregarding the financing in the first place, it has no effect on labour supply: this is the result of Step IV assumption of a long-run zero real wage elasticity of labour supply.

- However, now comes the financing: we tax all income proportionally to keep income distribution unchanged (respecting steps II and III).

- The overall result is that the marginal tax rate on incomes is increased for all, while the real net of tax incomes are unchanged for all persons also. If the productivity increase applies to all types of work capacity (paid work, black work and DIY), then we will see a shift away from paid work towards the last two activities plus fringe benefits in taxed work positions. The basic point is that the increase in productivity is benefiting all irrespective of their 
participation in the formal labour market, while their incentive to bid-in work in the formal labour market is reduced. By contrast, if the increase in productivity would only affect taxed work, then the result would be different.

\section{Example two}

Raise taxes on energy to save on energy:

- Energy use is positively related to work income: the richer you become, the more energy you consume. As any other consumption tax, an energy tax makes the value of the marginal basket of consumption that you can buy for your wage smaller.

- We now recycle the tax revenue in the form of a combination of a lump sum transfer and a VAT reduction that keeps net revenue and the income distribution unchanged.

- The marginal tax of consumption is then left broadly unchanged.

- In this situation, we would not expect any changes in the distribution of time between paid work, black work, DIY and leisure with some caveats on the margin. A higher energy tax creates incentives to spend more time creating your own energy (DIY as in chopping wood for your stove), or driving to a neighbouring country to buy lower taxed energy (pure waste of time from a welfare perspective). While a higher VAT just creates an incentive across the board to shift work efforts towards black economy and DIY. Therefore, the specific effects are different and these could be included in policy assessments.

The two examples presented above show that one should be very careful making distinctions between measures that affect the overall income and productivity levels in society across the board, as opposed to measures that make it more attractive to use a given set of skills in different uses i.e. taxed work, black economy, DIY or leisure. In other words, there are fundamental differences between policy measures that affect overall labour productivity and income levels, and policy measures that affects the marginal incentive to allocate time between the four dimensions keeping productivity unchanged. 


\subsection{Marginal cost of public funds}

When a policy package leads to a decrease in labour supply, e.g. through the effects of higher income taxes, this introduces a welfare cost in the form of a so-called Deadweight Loss (DWL) in the labour market. The DWL must be added to the cost-side of the analysis, and the implication hereof is that the actual cost of funding DKK 1 of public expenditure through the tax system will exceed DKK 1. In other words, costs will also include the opportunity cost of raising additional revenue in an already tax-distorted labour market. The total cost of financing DKK 1 through income taxation is thus the net budget cost (the net financing need) plus the DWL arising on the labour market, also termed the Marginal Cost of Public Funds (MCPF), cf. Box 1.

The mechanism is precisely that as the income tax rate rises, the value of working in terms of consumption possibilities is reduced. In other words, the relative attractiveness of allocating more time to not only leisure, but certainly also to non-taxed work and DIY increases. Indeed, there is strong cross-country evidence, that the effect on time allocation from differences in tax rates is as much a result of the two latter effects as it is the first. ${ }^{4}$

To precisely estimate the costs (i.e. not only assuming that the single response is more leisure), a number of key but difficult questions need attention:

- Non-taxed work in both own, and certainly other than own profession, is lower than own work in the formal taxed sector with the organisational advantages this confers: So how much lower productivity do we have when we do either DIY or black economy work instead of formal work?

- How large will the shift from "white" work towards DIY and "black" work be, and hence the loss in overall productivity?

- What is the initial distortion in the ratio of leisure to paid work due to the prevailing tax system, etc? If we start with zero taxes, a small increase in leisure leads only to a small distortion (the ratio of marginal gross wages to value of leisure is close to the net-of-tax wage to value of leisure). If we already have large differences in 
these two ratios, then a further increase in tax rates will imply a large distortion from an increase in tax induced leisure.

\section{Box 1: Marginal cost of public funds}

The cost of raising public revenue through the tax system involves a welfare loss in the form of a deadweight loss (DWL) in the labour market referred to as the excess burden of tax finance.

In addition to the direct net financing need - the budget cost - of the policy measure, the DWL must be added to costs, ensuring that the cost-side of the analysis includes all costs of public funds.

The Marginal Cost of Public Funds (MCPF) is then the ratio of total costs of public funds (associated with the instrument) to the incremental revenue raised, and reflects the total cost to society of financing DKK 1 through a tax on labour income, cf. (1).

$$
M C P F=\frac{\text { Total cost }}{\text { Incremental revenue }}=\frac{\text { Budget cost }+D W L}{\text { New revenue gained }- \text { old revenue lost }}(1)
$$

The below Figure illustrates the MCPF geometrically. Here, $w$ is the going market wage assumed fixed (hence the horizontal demand curve), $w-t_{0}$ is the initial after-tax wage and $w-t_{1}$ is the post-intervention after-tax wage and $l$ is labour supply.

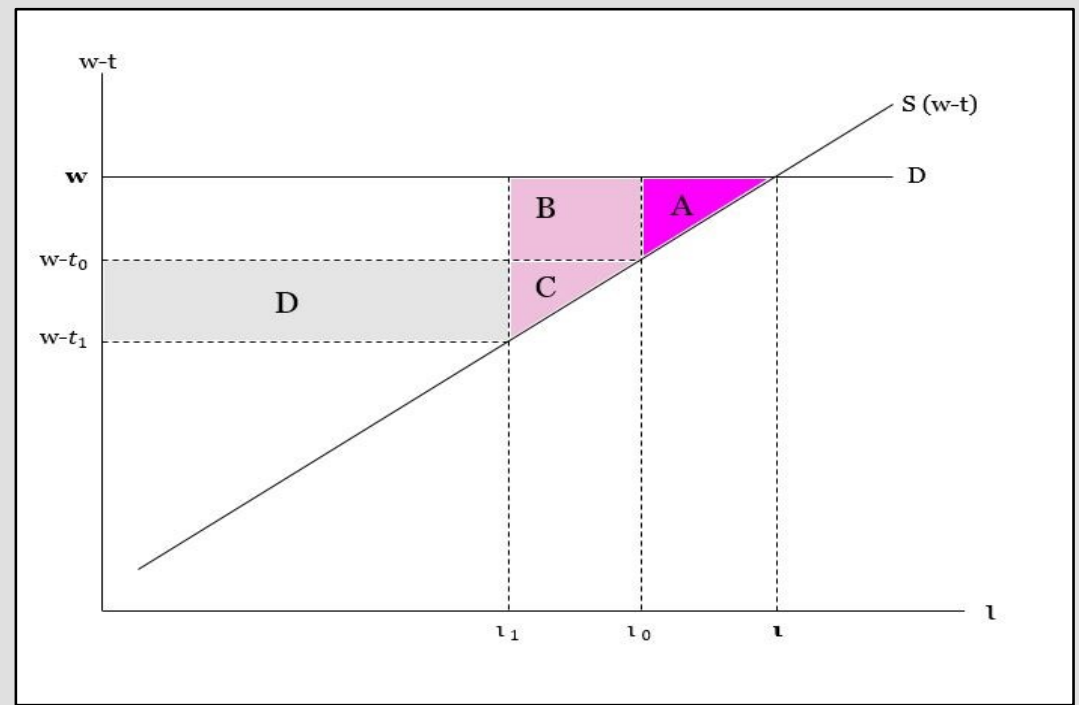

At the initial starting point the market is already distorted from the existing tax rate, $t_{0}$, resulting in an existing DWL given by area A. The new policy intervention requires financing and the tax rate will be raised from $t_{0}$ to $t_{1}$ 
resulting in a fall in labour supply from $\mathrm{t}_{0}$ to $\mathrm{t}_{1}$.

In terms of the areas highlighted in the Figure the MCPF from the intervention can then be written as:

$$
M C P F=\frac{\mathrm{D}-\mathrm{B}+(B+C)}{D-B}=\frac{D+C}{D-B}
$$

Where total costs are calculated as the new revenue raised (D) minus the loss in old revenue (B) plus the DWL arising on the (already distorted) labour market $(B+C)$. The incremental revenue raised is new revenue gained (D) minus old revenue lost (B).

Note that the higher the initial distortion (i.e. the higher the initial income tax rate $t_{0}$ ) the higher is the associated MCPF.

Source: Copenhagen Economics based on Boadway (2006).

\subsection{Assessing product market distortions}

Environmental policy measures are usually product market interventions. The explicit purpose is to change the behaviour of households and firms in order to achieve environmentally friendly solutions. In essence, interventions work by changing the relative price of goods and services and policy-induced price changes will distort existing product markets.

Below, we will go through some fairly standard, but very important, descriptions and illustrations of distortions in product markets assuming an efficient market prior to any intervention. It is important to note that even if the market was not efficient from the onset, e.g. in the presence of a negative externality, the correct way to undertake the CB-analysis would still be to include the arising product market distortion on the cost-side. The difference is that in this case there is now also a benefit to be included on the benefit-side stemming from the correction of the externality, e.g. by internalising the externality into production decisions. The intervention is profitable as long as benefits outweighs costs including the distortionary costs of using the particular policy instrument. 


\subsubsection{Theoretical approach - with no existing distortions}

An efficient market situation is where the demand and supply curves intersect. Here, the cost of supplying one additional consumer will exceed the benefit to the consumer. Hence, no efficiency improvements can be achieved, cf. Figure 1 .

Figure 1: Deadweight loss - with no existing distortions

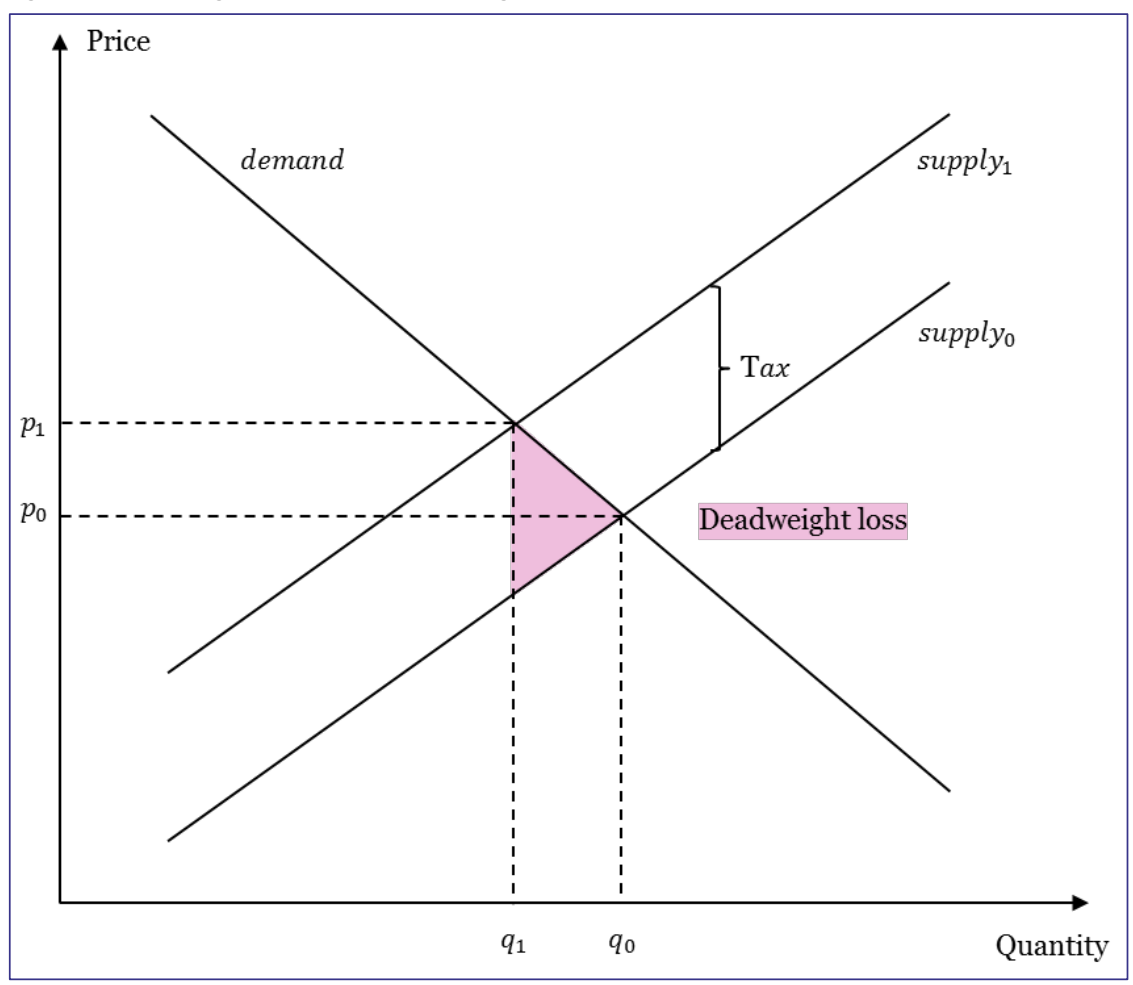

Source: Copenhagen Economics.

Policy interventions will distort the market. Imposing e.g. a product tax implies that the price of the good increases, and that a number of consumers will stop consuming - even though they value the product more than the private cost of producing it. This inefficiency implies a loss to society given by the sum of the loss in consumer and producer surplus, the so-called DWL illustrated by the shaded triangle in Figure 1.

The DWL must be added to the cost-side of the CB-analysis. It is also important that policymakers evaluate whether the product market intervention will lead to DWLs in other related goods markets. In that case, these should also be added to the cost-side in a similar manner.

However, the above simple example leaves out one very important feature typically present in the real world, which can significantly 
influence the size of the arising DWL in applied analysis, and thus the profitability of the policy intervention: existing market distortions.

\subsubsection{Theoretical approach - with existing distortions}

The impact of a given intervention depends on the initial market allocation. This is illustrated in Figure 2. Area A is the welfare loss from an initial intervention which raises the price with DKK 1 (from DKK 5 to DKK 6) and reduces demand with 1 unit (from 11 to 10 units). The larger area $B$ is the welfare loss from an equally large subsequent intervention, i.e. a price increase of yet another DKK 1 leading to yet another drop in demand of 1 unit. For ease of illustration only the consumer loss is considered in Figure 2 by assuming a horizontal supply-curve.

Figure 2: Deadweight loss - with an existing distortion

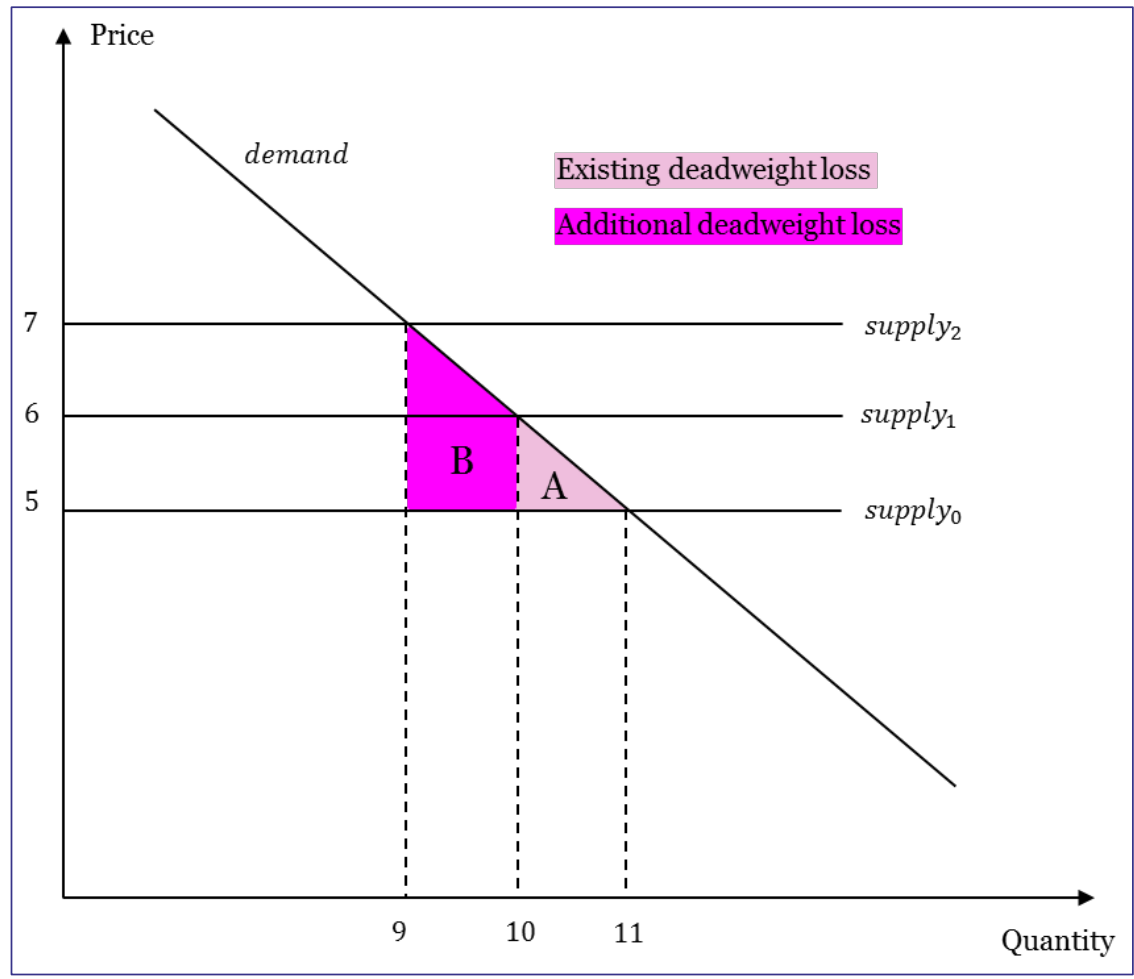

Source: Copenhagen Economics.

Given existing distortions, the welfare loss incurred by the equally sized latest intervention issubstantially higher than for the first. More specifically it is higher by the square area of area B. Deadweight losses can therefore be very high for interventions in pre-distorted markets. 
Box 2 outlines the minimum necessities in order to make a correct calculation of the distortion in a pre-distorted market.

\section{Box 2: Assessing product market distortions in practice}

Starting with a qualitative analysis the important question is: How important is the distortion from the intervention likely to be?

In order to assess this question it is necessary to ask a number of additional questions:

- How large is the intervention? I.e. by how much will the intervention, say a goods tax, change the after-tax price of the good?

- How distorted is the market from the onset?

- How elastic is the demand and supply responses? E.g., a fully inelastic demand response will give rise to the lowest welfare loss, as there will be no behavioural change. A fully elastic demand response implies no loss of consumer surplus as consumers have (almost) equally attractive alternatives, however there will be loss in producer surplus.

The quantitative analysis would require data on:

- The current market equilibrium, i.e. current quantity of consumption at the going after-tax market price.

- The estimated demand and supply elasticities in the particular market.

- A decomposition of the pre-intervention price into a "clean/factor" price excluding the impact of existing policy interventions (including taxes) affecting the price.

- Finally, the estimated price impact from the new intervention.

The price decomposition along with the demand and supply elasticities will enable the policymaker to assess the size of the existing distortions, i.e. the distance from the unregulated market equilibrium.

Example 1 in chapter 2, section 2.1 uses the above steps in order to calculate the costs of a particular policy intervention in an already distorted market, i.e. the market for electricity.

Source: Copenhagen Economics. 


\subsection{Distortions related to typical policy instrument categories}

The typical environmental policy instrument categories are listed in Table 1 along with the associated implications for product and labour market distortions we would suggest based on our four principles decribed in section 1.1. As argued earlier environmental policies are most often about product market interventions with the specific purpose of changing consumption or production behaviour, and the chosen categories cover a broad set of policy options.

Table 1: Policy measures and distortions

\begin{tabular}{|c|c|c|c|}
\hline $\begin{array}{l}\text { Environmental policy } \\
\text { measure }\end{array}$ & $\begin{array}{l}\text { Labour } \\
\text { market } \\
\text { distortion }\end{array}$ & $\begin{array}{l}\text { Product } \\
\text { market } \\
\text { distortion }\end{array}$ & Underlying assumption/Description \\
\hline $\begin{array}{l}\text { Table } 1 \text { Command } \\
\text { and control }\end{array}$ & $(v)^{1}$ & $v$ & $\begin{array}{l}\text { The long-run real wage elasticity of labour supply is } \\
\text { zero. }\end{array}$ \\
\hline Environmental taxes & & $v$ & $\begin{array}{l}\text { Keep budget balance unchanged and income } \\
\text { distribution constant. } \\
\text { Expected marginal tax effect of environmental tax } \\
\text { equals the effect from off-setting tax (recycling), i.e. no } \\
\text { double dividend. }\end{array}$ \\
\hline $\begin{array}{l}\text { Support for new } \\
\text { technology }\end{array}$ & $\checkmark$ & $v$ & $\begin{array}{l}\text { The benefits of the new technology fall to all: Taxed } \\
\text { work, un-taxed work and leisure } \rightarrow \text { no labour supply } \\
\text { impact. } \\
\text { The measure will require tax financing } \rightarrow \text { lower labour } \\
\text { supply. } \\
\text { So benefits in product markets (lower loss of consumer } \\
\text { surplus than higher tax rate) must pay for MCPF effects. }\end{array}$ \\
\hline User fees & & $v$ & $\begin{array}{l}\text { Keep budget balance unchanged and income } \\
\text { distribution constant. } \\
\text { Expected marginal "tax" effect equals the effect from } \\
\text { recycling revenue, i.e. no double dividend. }\end{array}$ \\
\hline
\end{tabular}

Note: ${ }^{1}$ Assuming that the measure will not require tax financing, there will be no labour market distortion.

Source: Copenhagen Economics.

Below, we will describe the different categories and the rationales behind the distortion statements in Table 1.

\subsubsection{Command and control (CaC) measures}

$\mathrm{CaC}$ measures cover e.g. the mandated use of certain production technologies, certain product requirements (mileage for cars, energy efficiency of electronic products, labelling of products, etc.) or mandated 
"end-of-pipe treatment" such as the use of emission filters. A more "radical" example is a full prohibition to the use of a certain product such as a mandatory scrap scheme, which also falls in the CaC category of instruments. We have included an example on how we propose policymakers should handle the cost-side of a mandatory scrap scheme with a gradual phase-out in example 2 , chapter 2 section 2.2 .

Typically, CaC interventions aimed at producers will increase their production costs and thus prices. The intervention will result in a DWL in the product marke that must be included on the cost-side of the analysis.

We suggest that policymakers do not include a labour market distortion from $\mathrm{CaC}$ measures. We base this recommendation on irrefutable empirical evidence that the long-run real wage elasticity of labour supply is zero - i.e. in the long-run, the income-effect of changes in the real wage is approximately of the same size as the opposing substitution-effect. ${ }^{5}$ The income effect incentivises households to work more (consume less leisure) in order to maintain the same consumption bundle after the drop in real wages. The substitution effect incentivises households to supply less labour as a fall in real wages will decrease the opportunity cost of leisure.

\subsubsection{Environmental taxes}

Optimally, taxes/subsidies should be set according to their marginal external cost/benefits, so-called Pigouvian taxes. These taxes will fully internalise externalities into production decisions to reach the social optimum level (where overall welfare is maximised) of consumption.

We suggest that policymakers only include product market distortions when estimating the costs of environmental goods taxes - i.e. we advice that any impacts on labour supply decisions are disregarded after applying a number of assumptions resulting in a "no double-dividends effect."

The double-dividends strand of literature from the early 90s argued that a double dividend could be realised if governments were to use revenue collected from new environmental taxes to reduce distortions in the labour market emanating from income taxation. ${ }^{6}$

First, the environmental goods tax is set to correct the negative externality ensuring that the price of the good equals its social marginal cost - a welfare gain. Next, the additional revenue collected is recycled

\footnotetext{
${ }^{5}$ See e.g. CE (2014) and Kimball et al. (2010).

${ }^{6}$ See e.g. Oates (1993), Pearce (1991) and Repetto et al. (1992).
} 
through a reduction of the distortionary income tax rate, which will increase labour supply as the opportunity cost of leisure rises. This will enable a higher consumption - welfare gain.

However, the double-dividends argument does not fully take into account interactions between environmental taxes affecting product markets, and income taxes affecting the labour market. Interactions suggest there is no dividend (welfare gain) from changes in labour supply - i.e. a double-dividend is not obtainable.

The net welfare effect of implementing the environmental tax can be stated as the sum of three effects: A primary effect, a revenue recycling effect and a tax-interaction effect. ${ }^{7}$

- The primary effect is the welfare gain attained from internalizing the environmental externality with the tax.

- The revenue-recycling effect is the welfare gain associated with a higher real net of tax wage from reducing the distortionary income tax rate.

- The tax-interaction effect is the welfare loss in the labour market from a lower real net of tax wage due to higher prices induced by the environmental tax.

If the impact on household's labour supply decisions is of the same magnitude for 2 and 3 there is no net impact on labour supply and thus no double-dividend. More specifically, for 2 and 3 to affect labour supply decisions identically (with opposite signs) they must have the same distributional profile, keeping the overall policy intervention distribution-neutral. ${ }^{8}$ Formulated in terms of utility, the income tax (revenue-recycling) scheme can be designed such that the exact same labour effort that maximized utility prior to the intervention will continue to do so for all levels of income after the intervention, i.e. workers stay on the same indifference curve. ${ }^{9}$

The assumption of distribution-neutrality is both convenient and makes sense from a policy perspective as in most cases the policy

\footnotetext{
${ }^{7}$ Discussion based on Parry and Oates (2000).

${ }^{8}$ As an example, energy taxes are regressive (i.e. the income elasticity of energy demand is below one) meaning that higher energy taxes are effectively a redistribution of income from poor to rich households. However, since the purpose is to instigate a behavioural change and not a redistribution, applying the standard assumption of distributional neutrality there is not much left of any double-dividends effects once policymakers have used lump sum transfers to compensate for the distributional impact (i.e. the regressiveness) of energy taxes.

${ }^{9}$ For details and a formal derivation of the result the interested reader is referred to Kaplow (2012) and Kaplow (2011).
} 
objective is not distributional, but the correction of a negative environmental externality.

Therefore, we suggest that the basic CB-analysis, when looking at product market interventions, should consider:

- Whether benefits (higher/lower positive/negative externalities) exceed the isolated loss of consumer welfare taking into account existing (pre-existing) product market distortions as illustrated in Figure 2.

- Forget as a rule about double-dividends given the assumption of no change in the desired income distribution.

While the design of a distribution-neutral policy package is a convenient assumption, it is recommended to clarify when a specific policy intervention is expected to have a significant impact on the income distribution. This could serve the purpose of designing an adequate offsetting tax instrument, or simply to include correctly the expected impact on labour supply in the analysis.

\subsubsection{Support for new technology}

Support (or subsidies) for new technology can be rationalized as there is a positive externality (spillovers) associated with research and development (R\&D), which left to the market will therefore be underprovided relative to the social optimal level, e.g. an underprovison of "clean-tech" R\&D activities.

Support can come in different forms, e.g. transfers to R\&D in cleantech or a subsidy to firms that chose to implement clean-tech in their production.

In general, such support measures will require tax financing and therefore lead to a distortion in the labour market, which should be included on the cost-side of the analysis, cf. the MCPF discussion in section 1.2 .

Whether the measure will also lead to a product market distortion depends on its price-quantity impact in the market for goods produced using the clean technology. If the support measure is high enough, marginal production costs could fall and prices follow and the consumer surplus on the goods market would rise (note the trade-off as the labour market distortion will be higher the higher the support measure). The gain in consumer surplus must be added to the benefit-side of the analysis along with the other benefits in terms of the avoided damages 
obtained from using a cleaner technology and the positive knowledge spillovers associated with more R\&D (a higher productivity).

\subsubsection{User fees}

We could characterise a user fee as reimbursement for costs that the operator of a plant, often publicly owned, is provided with. If the provision of services paid for provides welfare for recipients equivalent to the costs, then this is just like any market transaction.

The service provided to the customer may well have less value for the customer than for society as a whole.

A natural example might be when firms are forced to deposit waste at facilities that are subject to environmental standards, e.g. a high degree of recycling which imposes costs. The more stringent the requirement, the higher the costs all other things equal and, as a consequence, also the user fee because it is based on cost-reimbursement.

In essence, the policy intervention could be characterised as a $\mathrm{CaC}$ measure that in turn is converted into higher costs for waste management facilities, with costs recuperated from its customers. The additional costs will be contained to the extent that new value streams from recycling can compensate for higher costs.

The product market distortions are clear here. Higher costs for waste management industry as a whole while providing the same service to their customers, and additional loss of consumer welfare from the reduced demand for the kind of final consumption which leads disproportionally to waste generation.

There is a priori no labour market distortions. Basically, we have a reduction in consumer welfare and GDP but following our basic principle IV (zero long-run real wage elasticity), there is no reason that the allocation of work between different activities should be affected in general.

\subsection{How distortions are dealt with in existing guidelines}

Besides specific statements of the recommended size of the MCPF for DK, NO and SE the overall conclusion is that information/recommendations on the treatment of economic distortions in environmental policy analysis 
are sparse in the existing guidelines we have evaluated. ${ }^{10}$ This makes a comparison between countries and with the issues presented above difficult. Our approach has therefore been to focus on the most detailed set of guidelines (with respect to distortions), and include whenever possible recommendations and considerations from other guidelines, ensuring that we get around the existing recommendations.

The Danish guidelines, developed in 2013 as a tool to estimate the costs and benefits of different measures in the Danish climate plan, are the most detailed set of guidelines and will therefore serve as a "benchmark" for the assessment. ${ }^{11}$

We start with an evaluation of the most specific recommendation on dealing with distortions across (three of) the countries, namely the recommended size of the MCPF. Next, we move on to the treatment of interactions between product and labour market distortions.

\subsubsection{The recommended $M C P F$}

Recapping from section 1.4 the MCPF measures the cost of financing DKK/NOK/SEK 1 of public expenditure through the tax system taking into account the DWL arising in the labour market from a lower labour supply.

For both DK and NO the MCPF is set at DKK/NOK/SEK 1.20. However, SE guidelines recommend using a MCPF of DKK/NOK/SEK 1.30, cf. Box 3. Needless to say this difference will, everything else equal, result in costs being estimated $10 \%$ higher in SE compared to both DK and NO.

\section{Box 3: The applied size of the MCPF across guidelines}

When a measure results in a public net tax financing need a deadweight loss (DWL) will arise on the labour market from a lower labour supply. Three of the Nordic countries evaluated specifically state the size of this distortion (DWL):

- For DK and NO: $20 \%$ of the net budgetary financing need, i.e. MCPF=1.2.

- For SE: $30 \%$ of the net budgetary financing need, i.e. $\mathrm{MCPF}=1.3$.

More specifically, where DK and NO recommend that the net budgetary financing need from the policy measure is raised by $20 \%$ to account for the labour market distortion, SE guidelines recommend a $30 \%$ addition.

${ }_{10}$ We have evaluated guidelines from DK, NO, FI, and the UK. The country guidelines are stated separately under references.

${ }^{11}$ See ENS (2013) 
$20 \%$ is chosen as the social marginal cost of tax finance in DK and NO as it is assumed that the fiscal residual-instrument is the bottom tax rate. The $30 \%$ in SE guidelines is estimated by professor Peter Birch Sørensen based on a life cycle model which incorporates not only the loss of labour income tax revenue, but also consumption, business and savings tax revenue from higher taxes on labour.

Danish guidelines stand out by recommending a differentiated size of labour market distortion depending on whether the intervention affects relative prices or the tax rate. This is because changes in the tax rate only affects employed people whereas changes in prices affects both employed and unemployed people cf. Box 4.

\section{Box 4: The size of the labour market distortion - Danish guidelines}

Danish guidelines recommend using different distortionary impacts:

- Tax rate: Apply a 20\% labour distortion to the net public financing need.

Every 1 DKK raised through the tax system will result in a distortion on the labour market of the value of DKK 0.20 . In other words the MCPF=1.2. More specifically, the distortion is set at $20 \%$ of costs with a budgetary effect after having corrected this value by the net-tax factor ${ }^{1}$ in order to reflect the loss in consumption possibilities.

- Relative prices: Apply a labour distortion of $10 \%$ of the price increase.

Changes affect all (employed and unemployed) and there will be no change in labour supply for the unemployed. The distortion is therefore set at $10 \%$ of the price increase (again adjusted with the net-tax factor).

Note: ${ }^{1}$ The net-tax factor reflects the average level of taxes (direct and indirect) on private consumption. It is used to state costs/benefits in economic analysis as "losses/gains of consumption possibilities" making comparisons of costs for firms and the government comparable to costs for consumers. Applying the net-tax factor to costs will e.g. make costs reflect market prices, i.e. the consumer's willingness to buy (utility). 


\subsubsection{Distortions, measures and intercations}

Other than the MCPF we have found no discussions on which policy instruments are associated with what types of distortions, and how distortions can be interconnected besides Danish guidelines. Table 2 summarizes the recommended applied distortionary corrections from policy-induced changes in key measures.

Table 2: Distortionary corrections - Danish guidelines

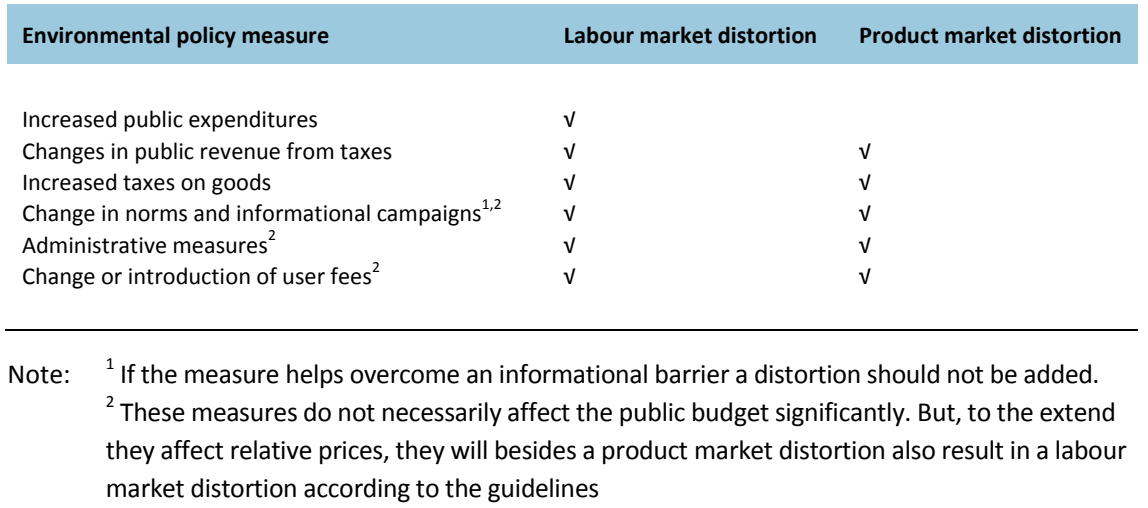

Source: Copenhagen Economics based on ENS (2013).

Judging from the Danish guidelines, labour market distortions will be added for most economic policy measures. This is because it is recommended adding a labour market distortion not only for measures resulting in a net tax financing need (MCPF), but also for all measures leading to a change in relative prices.

Using the example of a goods tax, Danish guidelines apply the following evaluation argumentation leading to a labour market distortion:

1. The increased tax will result in a DWL on the particular product market, but also a negative effect on labour supply from a lower marginal real disposable income.

2. To keep at balanced budget the new revenue is redistributed through the fiscal residual-instrument (bottom tax rate) which will work in the opposite direction of 1, i.e. a positive effect on labour supply from a higher marginal real disposable income.

Under the assumption of distributional-neutrality (same as our principle III in section 1.1), the net-effect on labour supply is zero and there will be no labour market distortion. 
However, Danish guidelines still suggest that a labour distortion should be added and write:

Yet, there will still be a labour supply effect from the DWL on the product market. Therefore, $20 \%$ should be added to take account of the negative effect on labour supply from the estimated product market DWL. 12

In summary, Danish guidelines recommend raising the DWL on the product market by $20 \%$ to take into account a labour market distortion even after applying the principles of a balanced budget and distributional-neutrality.

The argument is that consumers will supply less labour as the goods tax will decrease utility from consumption.

However, as discussed in section 1.4, under the assumption of a distribution-neutral policy package the impact on labour supply from the revenue-recycling effect and the tax interaction effect cancel out. In other words, the recycling tax instrument can be designed such that the same pre-intervention labour effort that maximized utility will continue to do so after the intervention, thus there should be no effect on labour supply.

Therefore, we are reluctant to approve of this addition. Nevertheless, the economic rationale behind it should be explained in guidelines, which it is not. ${ }^{13}$

\footnotetext{
12 ENS (2013), p. 18.

${ }^{13}$ It is understood that it is the ministries of Finance and Taxation that decides on the treatment of distortions, and that this particular result taken from the guidelines of the Danish Energy Agency, ENS (2013), are based on internal discussions between the three parts. An updated version of the 1999 general guidelines, FM (1999), from the Ministry of Finance should be underway, and is likely to contain a more thorough explanation of this particular recommendation.
} 



\section{Analytical examples}

In this chapter, we will go through four specific analytical examples. The examples have been selected with special attention on how to deal with the cost-side including economic distortions of CB-analysis.

- Example 1 - Removing a tax (PSO-tax) on the market for electricity.

This example looks at how policymakers in practice should evaluate product market distortions from policy interventions in pre-distorted markets.

- Example 2 - Mandatory gradual scrap schemes for wood burning stoves.

This example is chosen because it has a number of atypical (to CBanalysis) cost considerations, also related to the product market.

- Example 3 - Optimal design of car taxation.

This example is included as car taxation is rather complex. Cars are heavily taxed in the Nordic countries implying large deadweight losses from interventions, and car taxation has a number of interesting characteristics related to the degree of self-financing and thus labour market distortions.

- Example 4-A higher recycling of waste.

This example is chosen to illustrate the different cost complexities that the policymaker must take into consideration when designing policies that affect the process of waste treatment, here in terms of higher recycling. 


\subsection{Example 1: Removing the PSO-tax on the market for electricity}

The example illustrates the importance of taking into account existing (pre-intervention) distortions in the market.

More specifically, we estimate the socioeconomic net benefit of removing the Danish Public Service Obligation (PSO) tax on electricity and instead finance the PSO-expenses by taxing income. The revenue collected from the PSO-tax is predominantly used to support the development of sustainable energy.

Two effects are relevant to consider:

- The labour market: How will the restructuring of the PSO-expenses affect the labour supply?

- The product market: How will the restructuring distort the composition of consumption for households and the inputs used by firms?

Taking these two issues into account our conclusion is that the net benefit to society is likely to be approximately DKK 1.3 billion ${ }^{14}$ Below we will go through the calculation and discuss the conclusions the example would give rise to if we did not treat the distortions adequately.

\subsubsection{Impact on labour market}

The impact on the labour market is the sum of two opposing effects.

The reduction in the PSO-tax will contribute to a lower marginal tax on labour. The point is that taxes on energy consumption - like direct income taxes - reduces the benefit of working or working more. This is because wage earners will typically increase the consumption of energy when wages rise. When the tax on energy consumption is lowered, the marginal benefit of working will increase. This effect is both theoretically and empirically founded. ${ }^{15}$

The rise in income tax pulls in the other direction: the specific effect depends on the funding scheme. A reduction of the bottom taxallowance for income tax will only have marginal tax effects for persons with a very limited income, e.g. young persons below 18 working at the bakers or at the gas station, etc. A rise in the top bracket tax rate will on the other hand have a larger impact on labour supply.

14 Calculated as the total benefits minus the total costs: DKK 1.305-0.0343=1.27 billion.

${ }^{15}$ Se e.g. overview in Crawford (2008). 
The underlying assumption in this example is that the restructuring of the PSO-tax does not affect the economic distribution, i.e. we apply the assumption of distributional neutrality presented in section 1.1 and discussed in section 1.4. This is a good starting point for evaluating the impact of such measures as restructuring is motivated by a wish to improve the competitiveness for Danish firms, and not by a wish to redistribute between low and high incomes.

Under the assumption of distribution neutrality, the restructuring of the PSO-expenses is likely to cause only a negligible change of labour supply decisions if any. This means that the impact on marginal taxes from the removal of the PSO-tax roughly equals the impact on marginal taxes from the compensating finance of the PSO-expenses. Such a compensation package could consist of a lower bottom tax allowance, a higher tax rate at the bottom and a lower green-check, which is exactly meant as a compensation for energy taxes.

\subsubsection{Impact on product market}

Electricity taxes are common in the Nordic countries cf. Figure 3. Danish taxes (incl. VAT) means that Denmark by far has the highest market price of electricity despite having a factor price close to both the EU28 average and Sweden, Norway.

Figure 3: Electricity prices and (direct) taxes, Nordic countries, 2014

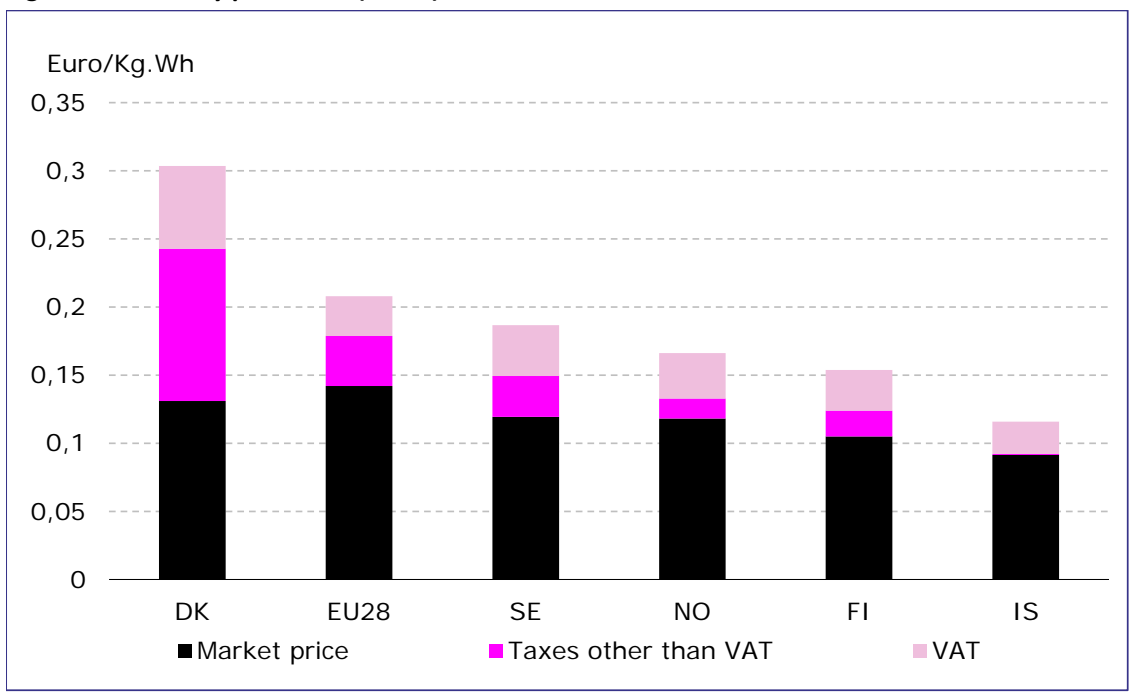

Note: The graph shows the domestic electricity price.

Source: Eurostat - energy price statistics. 
The multitude of taxes is important when it comes to understanding the impact on the product market from reducing taxation, in this example by removing the Danish PSO-tax which is just one of several of (direct and indirect) taxes levied on the market for electricity.

There are three types of taxes other than VAT in Denmark:

- A "quota-tax" from the $\mathrm{CO}_{2}$ quota system: This tax is an indirect tax and reflects the impact from the $\mathrm{CO}_{2}$ quota trading system on the price of electricity. The relationship between the two is uncertain, but the Danish Energy Agency (DEA) estimated that the price impact was approximately DKK $0.06 /$ Kwh for a quota price of DKK 100 /ton $\mathrm{CO}_{2}$ in $2007 .{ }^{16}$ We use this relationship in the analysis resulting in a quota-tax of DKK $0.047 /$ Kwh based on a forecasted quota price of DKK 78.9/ton $\mathrm{CO}_{2}$ in 2020 also performed by DEA.

- An electricity-tax:17 Today this tax is set at DKK 0.878/Kwh for households and DKK 0.04/Kwh for both small and large firms. ${ }^{18}$ In this example, a tax of DKK 0.30/Kwh is used based on a simple average over the three types of consumers. ${ }^{19}$

- A PSO-tax: The tax is used to fund public service obligations. Mainly subsidies for the development of renewable energy. Today the tax is set at DKK 0.211/Kwh for all consumers. ${ }^{20}$

The combined effect of the three taxes in the form of the arising distortionary-loss on the market for electricity is illustrated in Figure 4 below where we have assumed an inelastic supply curve.

When a tax is levied on the market for electricity, the price per unit of electricity no longer reflects the cost to the producer of producing one unit of electricity, and consumption is distorted. The distortion can be quantified as the DWL reflecting the loss in consumer and producer surplus caused by the tax.

The quota-tax raises the price of electricity by DKK $0.047 / \mathrm{Kwh}$ resulting in a DWL indicated by (the small) triangle A in Figure 4. The

\footnotetext{
16 http://89.233.45.21/skatteomraadet/publikationer/udgivelser/5453/5.kvoteprisenelprisenogvarmeprisen/ 17 The electricity-tax was introduced 1 st January 2014 and includes three former taxes: electricity-tax incl. an energy-efficiency contribution, electricity distribution tax and energy-savings tax and a surtax. The energy-savings tax was removed from 1 st January 2014.

${ }^{18}$ VAT-registered firms can recover the tax of their consumed taxable electricity except from $0.04 / \mathrm{Kwh}$. The refund does as a rule not apply to electricity used for heating. Lawyers, architects and agencies do not have access to refunds.

${ }^{19}$ See e.g. Table A.1 in appendix A.

${ }^{20}$ DEA 2015 based on data for electricity expenditures of Danish households 2013
} 
DWL from the quota-tax shall be included on the cost-side of the analysis even though the purpose of the quota system is to reach a social optimum level of electricity consumption/production. This is because all benefits to society of a reduction in electricity consumption will be handled separately on the benefit-side of the analysis using estimated unit prices (avoided damages) from different types of externalities (emissions). ${ }^{21}$

If an additional tax is levied on top of the existing quota-tax the DWL will rise relatively more as the market was already distorted. Therefore, even modest taxes can offset large distortionary losses on markets already subjected to other taxes. If we e.g. put the electricity-tax on top of the quota-tax, the price of electricity will have increased from DKK 0.658 /Kwh to DKK 1.005/Kwh and give rise to a combined DWL of not only triangles $\mathrm{A}$ and $\mathrm{C}$, but also rectangle $\mathrm{B}$.

Finally, we can put the PSO-tax on top of the two existing taxes and the DWL rises by triangle $\mathrm{F}$ and rectangles $\mathrm{D}$ and $\mathrm{E}$.

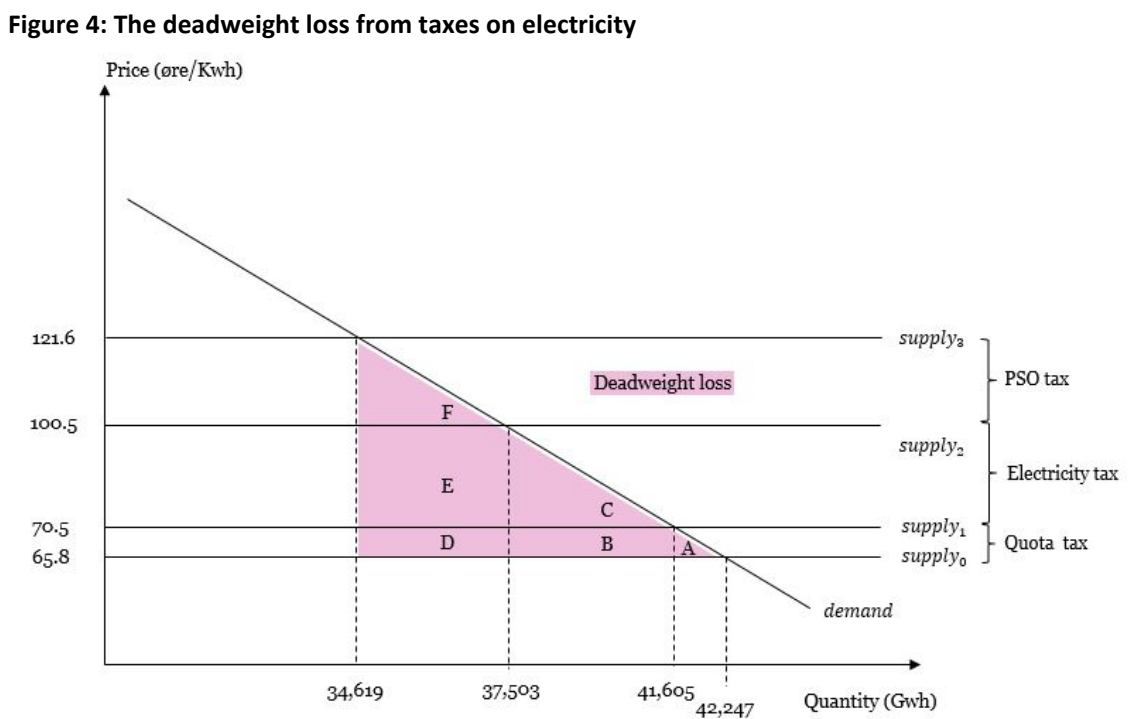

Note: Start at the market price of DKK 1.216/Kwh. Subtract the PSO-tax of DKK 0.211/Kwh to get DKK 1.005/Kwh. Subtract the average electricity tax of DKK $0.030 / K w h$ to get DKK $0.705 /$ Kwh. Finally subtract the quota tax of DKK $0.047 / \mathrm{Kwh}$ to get $65.8 \mathrm{Kwh}$.

Source: Copenhagen Economics, See appendix A for details and calculations.

${ }^{21}$ A Pigou tax will exactly have a size equal to the externality cost of production, fully internalising it into production decisions. By definition social welfare is maximized when the marginal cost of reducing an additional unit of emission (here the marginal loss in consumer surplus) equals the marginal social benefit (here the avoided damages) from a reduction in emission. Beyond this point, raising the tax further will cause a welfare loss as the shadow price will exceed the unit price of the environmental tax. 
The aggregated DWL of the three taxes is equal to $A+B+C+D+E+F$ in Figure 4. Converted into DKK this amounts to approximately 2.1 billion, cf. Table 3 which summarises the costs. The benefit of removing the PSOtax alone - in terms of the distortionary costs removed - can thus be estimated at approximately DKK 1.31 billion.

Table 3: Deadweight loss (million DKK)

\begin{tabular}{lrr} 
& Deadweight loss (million DKK) & Tax (DKK/Kwh) \\
Quota-tax (A) & 15 & 0.047 \\
Electricity-tax (B+C) & 808 & 0.030 \\
PSO-tax (D+E+F) & 1,305 & 0.211 \\
Total & 2,128 & \\
\hline
\end{tabular}

Note: See appendix A for details on data and calculations.

Source: Copenhagen Economics.

The cost of removing the PSO-tax comes in the form of damages to society from higher emissions and other pollutants following a rise in the consumption of electricity. For simplicity, we here focus on the cost of higher $\mathrm{CO}_{2}$ emissions. Adding other costs are not likely to alter the conclusion of positive net-benefits from reducing the PSO-tax due to the large relative size of the reduced distortion.

The cost incurred by higher $\mathrm{CO}_{2}$ emissions can be estimated as the expected change in emissions from increased consumption times the damage to society per unit of $\mathrm{CO}_{2}$ emission. The damage to society from a unit of $\mathrm{CO}_{2}$ emission is called the unit price or the "social cost of carbon." We proxy the unit-price by the $\mathrm{CO}_{2}$ quota (mid) price forecast for 2020 from DEA of DKK 78.9/ton. ${ }^{22}$ If the European quota system is designed optimally, then the quota price should equal the unit price. It is out of scope of this report to assess the functioning of the European quota system including to what extend the quota price deviates from the actual unit price of $\mathrm{CO}_{2}$ emissions. ${ }^{23}$

The expected rise in electricity consumption from removing the PSOtax is approximately $2,884 \mathrm{Gwh}$. For the $\mathrm{CO}_{2}$ emission related to electricity consumption the 2020-forecast is again used, resulting in an emission of 150 gram $\mathrm{CO}_{2}$ per Kwh. Thereby, cost are estimated at approximately DKK 34.3 million. The calculations are summarised in Table 4.

22 ENS (2013) og ENS (2014)

23 Estimating the social cost of carbon is prone to high uncertainty and disagreement. For details and discussions the interested reader is referred to Ackerman and Stanton (2010), IWG (2013), Nordhaus (2011) and Watkiss (2006). 
Table 4: The cost of removing the PSO-tax

$\begin{array}{lr}\text { Input variables } & \text { Values } \\ & \\ \text { Estimated change in consumption of electricity } & 2.9 \text { billionkwh } \\ \mathrm{CO}_{2} \text { emission per unit of electricity consumption } & 150 \text { gram/Kwh } \\ \text { Estimated change in } \mathrm{CO}_{2} \text { emissions from removing the PSO-tax }(=2.9 * 150) & 435 \text { billiongram } \\ \text { Used unit price of } \mathrm{CO}_{2} \text { emission } & \text { DKK } 78.9 / \text { ton } \\ \text { Estimated cost of removing the PSO-tax }(=435,000 * 78.9) & \text { DKK } 34.3 \text { million }\end{array}$

Source: Copenhagen Economics based on data from DEA.

The net benefit of removing the PSO-tax can then be calculated as the benefit of removing the PSO-tax (in terms of the reduction in the existing DWL on the market for electricity equal to DKK 1.31 billion) minus the associated cost (in terms of the social damages caused by higher $\mathrm{CO}_{2}$ emissions equal to DKK 34.3 million). This gives a net benefit of approximately DKK 1.27 billion.

This example illustrates the importance of considering the level of pre-existing distortions, as they are likely to affect the profitability of policy interventions significantly.

\subsection{Example 2: A gradual mandatory scrap scheme for old wood burning stoves}

Wood burning stoves are used for heating, typically in one-family houses. They have the unwanted negative externality of emitting vast amounts of particles threatening health conditions. It is estimated that particle emissions from wood burning stoves annually cause up to 200 premature deaths in Denmark and that old wood burning stoves (prior to 2005) account for approximately $80 \%$ of these emissions. In this example, we evaluate the costs (including distortionary costs) of addressing the emission problem from old wood burning stoves using the policy instrument "a gradual mandatory scrap scheme for old wood burning stoves."

Such a scrap scheme works by prohibiting the use of stoves produced prior to say 2005 from say the year 2017, usually allowing people an adjustment period where they can switch to alternatives, e.g. replace their old stove with a new (less emitting) model.

A full CB-analysis of the particular instrument has already been carried out for the Danish Environmental Protection Agency (DEA) and we will therefore evaluate the treatment of the cost-side of this 
analysis, i.e. the estimated shadow price of the scheme. ${ }^{24}$ Remember that the shadow price is the full cost of the policy measure divided by the change in emissions obtained. In other words, the shadow price measures the average cost of reducing one unit of emissions using a particular policy instrument.

To evaluate the cost-side of the measure we will apply the same underlying assumptions as in the analysis for DEA. They are:

- The amount of stoves over time is fixed in each period (year) at 750,000 and only the composition of stoves (old vs new) will change over time. Without the policy intervention, the change in composition happens automatically as households at a given pace voluntarily chose to replace old stoves with new stoves. The periodical voluntary replacement is estimated and is termed "the baseline scenario".

- The policy measure will not lead to a larger or smaller quantity of stoves, but only work by expediting the replacement of old for new stoves relative to the baseline scenario. The number of faster replacements due to the scrap scheme is estimated at 220,000 stoves over the considered period 2013-2030. As old stoves emit more than newer ones, the result will be that overall emissions over time will be reduced above the (voluntary) baseline scenario.

- The additional reduction in emissions (PM2.5) obtained from 220,000 faster replacements is estimated at 23 million $\mathrm{kg}$.

The entire benefit of the intervention can then be obtained by multiplying this reduction by the unit-price (for PM2.5).

For simplicity and similar to the analysis carried out for DEA we start by assuming that there are no costs to government, and only consider the economic costs as the costs incurred by households.

We make three other simplifying assumptions:

- There is no difference in private benefits for households from an old versus a new stove.

- The lifetime and depreciation rate is the same for old and new stoves.

- The price of a new stove is the same as the price of an old stove and set at DKK 13,000 as in the analysis for DEA. 
Thus, the "only" material difference is that new stoves have lower social costs as they emit less particles.

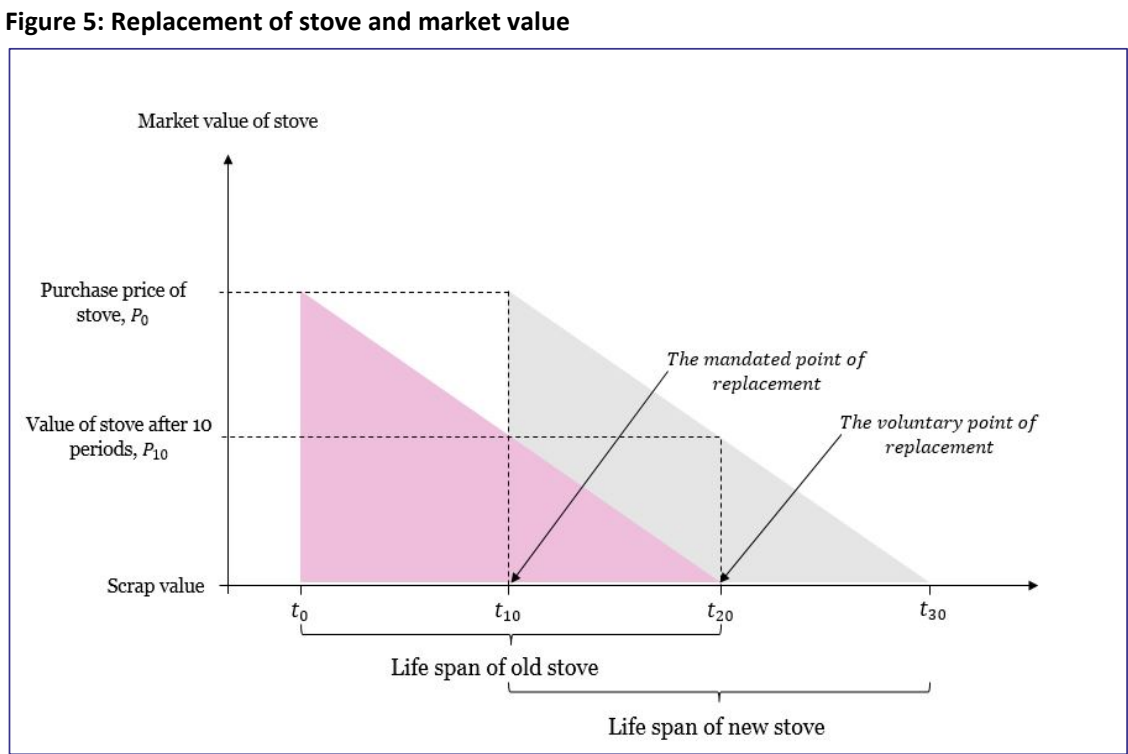

Source: Copenhagen Economics.

At time $t_{0}$ the household has purchased a stove at the market price $P_{0}$. The lifetime of the stove is 20 years and depreciates linearly, i.e. after 20 years the stove can no longer provide heating services and the market value is equal to its scrap value. Without any intervention households will voluntarily replace their old stove with a new one after 20 years illustrated by the voluntary point of replacement in Figure 5 .

After introducing the scrap scheme, some households will be forced to replace their old stove prior to the point in time where it has fully depreciated in value. In Figure 5 this is illustrated for an old stove with a remaining lifetime of 10 years at the mandated point of replacement as formulated in the policy measure. Here, the remaining value of the old stove is the original purchasing price adjusted for 10 years of depriciation, i.e. $P_{10}$.

The central question is then: How should we evaluate the costs of such a scheme?

To start with, it is important to remember the underlying assumption that all households will eventually replace their old stove anyway, i.e. without the policy intervention. This means that households 
will voluntarily at some point eventually spend the full replacement cost, ${ }^{25}$ say when the lifetime of the old stove expires (user value in terms of heating services is fully depreciated). The replacement cost should therefore not be included in the analysis, as it cannot be attributed to the policy intervention per se.

Rather, the costs arising from the scrap scheme are associated with the cost of forcing households to make the replacement earlier than intended without the policy intervention, plus the possible loss of consumer surplus (DWL) on the market for stoves. We will argue that these considerations boil down to three types of costs that the policymaker should include:

- The alternative investment cost: This is the loss equal to the expected return on the financial market from having to invest the purchasing price of a new stove $x$ number of periods prior to what the consumer intended to, had the policy intervention not been implemented.

- The lost value of owned old stove: This is the cost associated with having to scrap your old stove before it has fully lost its market value (i.e. has fully depreciated).

- The traditional deadweight loss (DWL): We will also discuss how, ideally, the policymaker should think about and attempt to include the traditional DWL (loss of consumer surplus) associated with a scrap scheme intervention.

Below we will treat each type of cost more specifically.

\subsubsection{The alternative investment cost}

With the mandatory scrap scheme some households will be forced to replace their old stove and pay the expense of a new stove $\mathrm{x}$ number of periods prior to what they initially intended. As argued earlier the purchasing price of a stove is DKK 13,000. The opportunity cost is then the risk free return the household could have earned on a DKK 13,000 investment for $\mathrm{x}$ periods.

Assume that the consumer is forced to replace his old stove with a new one 10 periods earlier than he intended to prior to the policy measure as illustrated in Figure 5. Assume also that he could instead have placed the DKK 13,000 in a 10-year government bond at an annual

${ }^{25}$ Replacement costs are e.g. the purchase price of a new stove plus possible installation and time costs. 
rate of say $2 \%$. This would have earned him a total return of DKK 2,847.26 Money he e.g. could have used to buy his new stove at the end of the lifetime of his old stove.

\subsubsection{The lost value of old stove}

If the consumer had voluntarily chosen to replace a new stove after 10 periods, then he would be able to sell his old stove at the going market price to pay part of the cost of a new stove. The market value of a 10 year old stove is the initial purchasing price adjusted for 10 years of depriciatons plus any potential scrap value obtainable when the stove can no longer provide heating services, cf. Figure 5 . The market value of a purchased stove thus depends positively on its expected remaining lifetime.

What happens when the scrap scheme enters into force? The remaining market value of the stove instantly drops to zero as there is no longer a market (demand) for old stoves - its use is prohibited. This is a loss to the consumer as

- he is prohibited from deriving utility from the remaining heathing services of his old stove

- he no longer has the option of selling his old stove on the used market for stoves at the market price (the monetary value of remaining heating services).

With the depreciation assumption in Figure 5, the lost value would equal half the original purchase price after 10 years, i.e. DKK 6,500. This cost should always be included.

How should we think about deadweight losses in this case, i.e. reduction in consumer surplus and should it be added to costs?

\subsubsection{The traditional deadweight loss}

The DWL is the loss of consumer surplus in the market for stoves from the policy intervention. Summing the difference between the willingness to buy and the purchase price across all individual consumers gives us the total consumer surplus (welfare).

${ }^{26} 13,000 *(1+0,02)^{\wedge} 10-$ DKK $13,000=2,847$. 
Remember, stoves have an assumed lifetime of 20 years. When the consumer bought his now 10 year old stove 10 years ago, he decided on his willingness to buy, keeping in mind that the product would last 20 years.

When the scrap scheme enters into force, the stove is no longer a product with a 20 year, but now only a 10 year, lifetime. Had the consumer known this when he bought his stove 10 years ago, his willingens to buy would naturally have been lower. Assume, similar to the market price of a stove, that the willingness to buy for all consumers depends positively on the expected lifetime of the product. Assume also that the willingness to buy when the product is fully depreciated is zero and equal to the market price. Then, the scrap scheme (effectively making the stove a product with a 10 year lifetime) will have halved the initial consumer surplus. In other words, the DWL of the scrap scheme is half the initial consumer surplus after 10 years.

It has not been possible to estimate this consumer surplus since good data on prices, consumption and price elasticities of stoves does not exist. In the below calculation of the shadow price we will therefore disregard this DWL as it is highly uncertain. It should however be noted, that this would in our opinion be the correct way to include the DWL. Also, it is worth noting that the cost from the DWL, as for the other two types of costs, approaches zero the older the replaced stoves are (the fewer expected years the have left).

\subsubsection{The shadow price}

To arrive at the shadow price we need to add the costs described above over time, apply a proper discounting rate to arrive at the present value of costs and then divide this value by the obtained change in emissions. Remember, this change was estimated at 23 million kg of PM2.5 for an additional replacement of 220,000 stoves.

Both types of costs are very sensitive to the assumed remaining lifetime of old stoves at the mandated point of replacement. Here, we start by assuming that 10 years remain as was illustrated in Figure 5.

As argued earlier, using an interest rate of $2 \%$ the household could have earned a return of DKK 2,847. For a total replacement of 220,000 stoves this amounts to a total cost of DKK 626 million.

To this, we should add the loss in value of old stoves, which is half the purchasing price of DKK 13,000 after 10 years, i.e. 6,500. For a total replacement of 220,000 stoves, this amounts to an additional cost of DKK 1.43 billion. 
Total costs can then be estimated at approximately DKK billion 2.1.

So far, we have not considered time discounting. We do this by applying a simple assumption, namely that replacements take place at two future points in time with half being replaced 5 years from now and the other half 10 years from now, i.e. 110,000 stoves at each point. We can then calculate the discounted value applying a discount rate of $4 \%$ as recommended in the Danish guidelines. ${ }^{27}$

Table 5 summarizes the cost calculations, and the estimated shadow prices depending on the assumed remaining lifetime of old stoves under the scheme, at the time of mandatory replacement. We see that the assumed lifetime affects both types of costs and that the result is highly dependent on this with the shadow price approximately halved when going from a remaining lifetime of 10 to 5 years.

Table 5: Summary and statement of costs

\begin{tabular}{|c|c|c|c|}
\hline \multicolumn{2}{|c|}{ Remaining life of old stove at mandated point of replacement } & 10 years & 5 years \\
\hline \multicolumn{2}{|c|}{ a. Alternative investment cost, DKK } & $626,324,041$ & $297,671,097$ \\
\hline \multicolumn{2}{|c|}{ b. Lost value of owned stove, DKK } & $1,430,, 000,000$ & $715,000,000$ \\
\hline \multicolumn{2}{|c|}{ c. Total cost $(a+b)$, DKK } & $2,056,324,041$ & $1,012,671,097$ \\
\hline \multicolumn{2}{|c|}{ d. NPV 5 years reaction ${ }^{1}$, DKK } & $845,074,235$ & $416,170,912$ \\
\hline \multicolumn{2}{|c|}{ e. NPV 10 years reaction ${ }^{1}$, DKK } & $694,589,421$ & $342,062,154$ \\
\hline \multicolumn{2}{|c|}{ f. Total NPV (d+e), miillion DKK } & 1,540 & 758 \\
\hline \multicolumn{2}{|c|}{ g. estimated units of reduced PM2.5, kilo } & $23,000,000$ & $23,000,000$ \\
\hline \multicolumn{2}{|c|}{ Shadow price (f/g), DKK } & 67 & 33 \\
\hline \multicolumn{4}{|c|}{$\begin{array}{l}\text { Note: }{ }^{1} \text { It is assumed that the total number of replacements }(220,000) \text { will be taken with half } 5 \\
\text { years from the policy adoption and the other half } 10 \text { years after. Each time with consumers } \\
\text { forced to replace a stove with a remaining lifetime of } 10 \text { ( } 2 \text { nd column) or } 5 \text { ( } 3 \text { rd column) } \\
\text { years at a constant price of DKK } 13,000 \text { for a stove. }\end{array}$} \\
\hline
\end{tabular}

Our cost calculation differs from the one applied in the analysis for DEA, cf. Box 5.

\section{Box 5: The cost calculation in the analysis for DEA}

Our calculation differs from the one carried out for DEA. In the analysis for DEA total costs are stated as the replacement cost of 220,000 new stoves. The replacement cost is simply calculated as the purchasing price of a new stove plus the money value of time spent replacing a stove.

${ }^{27}$ ENS (2013) 
Source: Copenhagen Economics based on Miljøstyrelsen (2013).

We have made a number of simplifying assumptions above, but they do not change the qualitative conclusion.

A more correct estimation of the costs would of course involve an assessment of:

- The weighted remaining lifetime of all stoves to be replaced at the time of the adoption of the policy measure, the mandatory point of replacement in Figure 5. A lower remaining lifetime would reduce both types of costs and the estimated shadow price is highly sensitive to this assumption, cf. Table 5.

- The price, lifespan and depreciation rates of old vs new stoves. We have just assumed identical parameters.

\subsection{Example 3: Car taxation}

Car taxation is interesting due to a number of complexities:

- The market for cars is affected by several existing policy measures.

- Car usage causes several different external social costs.

The focus of this example will be on the specific complexities related to car taxation that policymakers should pay attention to, including impacts on labour and product market, when doing CB-analysis in the area of car taxation.

\subsubsection{A wide range of product market interventions}

The market for consumer cars is likely one of the most heavily regulated and taxed markets in any of the Nordic countries (and many other European Countries). Box 6 below demonstrates that clearly:

- High level of taxation of diesel and gasoline in all Nordic countries based on energy content (well above EU minimum rates). 
- Substantial purchase taxes on consumer cars in all countries but Sweden, with formal rates reduced depending on a wide range of environmental motivated parameters.

- Concurrent, often yearly, user charges for owners of cars depending on a range of factors such as weight, but also environmental factors.

- Congestion motivated taxes when driving in Oslo and Stockholm with a discount for environmental friendly cars and reduction of parking fees for electrical cars in Copenhagen, Oslo and Reykjavik.

- EU Car fleet efficiency standards raising costs of cars with higher than average fuel consumption and an EU biofuel directive providing incentives for biofuel input until 2020 and lifting prices of car fuels.

\section{Box 6: Car taxation in the Nordic countries}

\section{Denmark}

Taxation of fuels (EUR per litre):

- $\quad$ Gasoline $=0.89$ Diesel $=0.7$

\section{Taxation of car:}

- Registration tax: Depends on fuel consumption, particle emissions and price. The taxable value of the car is increased by $105 \%$ for the amount below DKK 81,700 and $180 \%$ for the amount above to arrive at the registration fee. Finally, the fee is reduced based on fuel efficiency. Electric and brint cars are exempt from the fee.

- Annual tax: Differentiated for petrol and diesel cars. Reduced taxes for electric cars.

- Other: Third party liability tax. Number plate tax, environmental tax and a small tyre tax.

- Exemptions: Electric cars are exempt from parking fees in Copenhagen.

\section{Sweden}

Taxation of fuels (EUR per litre):

- Gasoline $=0.87$ Diesel $=0.8$

\section{Taxation of cars:}

- Registration tax: No registration fees in Sweden. Green cars are given a prize of 10,000 based on efficiency and particle emissions.

- Annual tax: Based on $\mathrm{CO}_{2}$ emissions. Annual fee for 2005 models or older is based on weight. For 2006 and younger, it is based on $\mathrm{CO}_{2}$ emissions. A five year exemption is granted for green cars incl. petrol cars with low $\mathrm{CO}_{2}$ 
emissions, electric and hybrid cars.

- Other: Congestion dependent tax in Stockholm on entry/exit.

- Exemptions: Ethanol, gas, electric and hybrid cars are exempt from congestion tax.

\section{Norway}

Taxation of fuels (EUR per litre):

- Gasoline $=0.51$ Diesel $=0.4$

\section{Taxation of cars:}

- Registration tax: tax between 11-67\% of car price depending on weight, efficiency and $\mathrm{CO}_{2}$ emissions. Re-registration depends on weight and age.

- Annual tax: Annual fee depends on the engine type (petrol or diesel) and particle filter. Electric cars are exempt from the fee.

- Other: Toll ring in Oslo.

- Exemptions: Electric cars are exempt from parking fees and toll in Oslo.

\section{Finland}

Taxation of fuels (EUR per litre):

- $\quad$ Gasoline $=0.9$ Diesel $=0.7$

Taxation of cars:

- Registration tax: Depends on $\mathrm{CO}_{2}$ emissions. Rates vary between $12.2 \%$ for cars emitting less than $60 \mathrm{~g} / \mathrm{km} \mathrm{48.8 \%} \mathrm{for} \mathrm{cars} \mathrm{emitting} \mathrm{more} \mathrm{than} 360 \mathrm{~g} / \mathrm{km}$.

- Annual tax: Based on $\mathrm{CO}_{2}$ emissions.

- Other: n.a.

- Exemptions: n.a.

\section{Iceland}

Taxation of fuels (EUR per litre):

- Gasoline $=0.3$ Diesel $=0.41$

\section{Taxation of cars:}

- Registration tax: Depends on size. A goods tax of $20 / 27 \%$ of total car price and $30 / 45 \%$ of trade price for small/large cars above/below 2,000 cc.

- Annual tax: Depends on weight.

- Other: n.a.

- Exemptions: Free parking for electric cars in Reykjavik. 


\section{Two key EU Policies}

Fuel Efficiency standard

The EU has adopted a directive which requires that companies marketing cars for the EU market should fulfil minimum fuel efficiency requirements calculated as an average over the total flow of cars sold every year, with adjustments for weight and with some provisions from niche makers of specialised typically expensive and highly energy consuming cars. This is de facto a so-called non-regulatory tax on fuel consuming cars, which ultimately translates into a higher price for fuel consuming cars: any additional car sold for a car operating close to the minimum requirement requires it to increase efforts to save energy use for the entire fleet. This implies that the optimal price for fuel intensive cars are set above pure construction costs to offset additional costs for the company to meet the fleet standard.

\section{Biofuel Policies}

Until 2020, providers of fuels to cars and other road transportation vehicles have to blend in $10 \%$ biofuels in the overall fuel. As biofuels currently are more expensive than either pure diesel or gasoline, this requires that the overall sales price goes up to compensate for the higher costs all other things equal.

Source: Copenhagen Economics. For fuel taxes Eurostat Energy price statistics (data 2014), except for Norway and Iceland where OECD (2013) is used (data 2013). For other taxes Copenhagen Economics based on Duer et al. (2011).

\subsubsection{A wide range of external social costs}

Car usage inflicts a number of external costs on society. Conventional diesel/gasoline driven cars emit $\mathrm{CO}_{2}$, their exhausts contain also particles that cause health damages, and they also produce noise, etc. at the local level, particularly when driving in densely populated areas.

Moreover, at peak hours each additional car driver on an already congested road, reduces the speed with which other drivers can reach their destination. This is then not an externality to society at large, but rather an argument for spreading traffic over a larger period of time to the benefit of cars users as a whole. These costs can be substantial as also documented in a number of international studies. ${ }^{28}$ 
As this study is not about CB-analysis per se, but with a particular focus on the cost-side, we will not venture further into these issues, but just note the complexity also of the benefit-side of the analysis.

\subsubsection{Calculating the product market distortion}

It goes without saying that the application of a wide a range of instruments have a substantial impact on consumer behaviour. In other words, the "neutral" situation with zero specific regulation on car use would lead to a very different market situation than the actual position of the five Nordic countries.

This in turn implies that any CB-calculation of changes in the regulation of car use is fraught with difficulties. A few obvious examples:

- The consumer loss calculation is highly complicated. All other things equal, consumers will relative to a "neutral" policy environment drive in fewer, older, less sporty and luxurious cars and drive fewer kilometres in the car they own. What is the costs to the consumer, bearing in mind also his individual benefits from less congestions when he drives?

- Instruments are overlapping and with some instruments potentially wholly or partly ineffectual at the margin. Example, the EU fleet standard implies that the average car sold by each car-producing firm has a fuel efficiency which exceeds a certain minimum for the cars sold in the EU market. However, it is unclear how much this will impact on consumers choice of cars, particular if taxes on fuel use are already very high: in other words, consumers might well in aggregate have chosen to buy cars with a higher fuel efficiency than the required minimum standard. If so, what we are left with is the product market distortions deriving from imposing common standards on car producers operating very different in different segments of the car market.

- The interaction between instruments can also be difficult to evaluate: a high registration tax implies that the average car on the road will be older - thus often less fuel efficient - but the effects of high fuel taxes and annual owner fees depending on fuel performance will tend to pull in the other direction.

- As documented in Box 6 above, taxation of car owners in all countries imply favouring cars with high fuel efficiency and/low $\mathrm{CO}_{2}$ 
emissions. This implies very high implicit taxes on $\mathrm{CO}_{2}$ emissions taking into account both the high energy taxes on fuel and the very fact that car ownership-taxes by itself is an implicit, if ineffective, way of discouraing purchase of consumer goods with an above average $\mathrm{CO}_{2}$ emission relative to other consumer goods. Therefore, any additional incentive to reduce $\mathrm{CO}_{2}$ intensity will have a very high shadow price. In Denmark it may well exceed DKK 4,000/ton. ${ }^{29}$

Hence, product market distortions may have many dimensions:

- The market usercosts (UC) for car transportion exceeds factor UC by a wide margin leading to the standard loss of consumer welfare.

- The incentives for producers to favour specific product characteristics such as fuel efficiency move their innovation efforts towards actions that favour such results.

Indeed, these distortions are to be expected for a successful environmental policy, the purpose of which is to reduce activities that are harmful to society at large.

However, as mentioned the essence of our report is to shed some light on the cost-side with a particular focus on economic distortions, and we have set-up a simple calculation example to illustrate key points when dealing with car taxation.

As a point of departure, we calculate the annual factor usercost (UC), i.e. the cost of car consumption net of all taxes, associated with buying a mid-range gasoline family car. The calculated UC takes into account both purchase, variable and fixed costs.

Then we calculate the market UC (i.e. including all tax components) for the same car and compare the annual and total (over the car's lifetime) differences in factor and market UC.

The difference between these two measures is the total additional costs that the car owner face due to the effects of the various components of taxes paid related to ownership and use. For simplicity, we abstain from any inclusion of the effects following from non-tax regulation such as rules limiting emissions of health damaging particles and fuel efficiency requirements.

Using Denmark, UCs are calculated for a gasoline car at the purchasing price of DKK 125,000 that drives $20,000 \mathrm{~km}$ a year at 19

${ }^{2929}$ See Copenhagen Economics (2012). 
$\mathrm{km} / \mathrm{l}$ and has an expected lifetime of 16 years. The result is that the market UC is higher than the factor UC by a factor of 1.73 , equivalent to DKK 24,200 annually or DKK 387,200 over the car's expected lifetime, cf. Table 6.

Table 6: Table 6 Annual usercost of cars (DKK)

\begin{tabular}{lrrr} 
& Factor usercosts & Market usercosts & Difference \\
& & & \\
1. Purchase cost & 7,800 & $23,500^{1}$ & 15,700 \\
2. Variable cost (maintenance, tyres, gasoline) & 17,500 & $24,800^{2}$ & 7,300 \\
2.1 Gasoline cost & 5,100 & $12,400^{2}$ & 7,300 \\
3. Annual fixed cost & 8,000 & $9,200^{3}$ & 1,200 \\
Total usercost (1+2+3) & 33,300 & 57,500 & 24,200 \\
& & & \\
\hline
\end{tabular}

Note: $\quad{ }^{1}$ Includes VAT and registration fee. ${ }^{2}$ Variable costs only differ based on gasoline taxes where energy-taxes, $\mathrm{CO}_{2}$-taxes and VAT on gasoline are added.

Source: FDM for car budget data and annual owners' fee. Energy and oil forum (eof) for gasoline prices incl. and excl. taxes.

The large difference between factor and market UC implies that the existing total DWL associated with the present system is very large. Costs are high due to the fact that taxes constitute a large share of the total costs of car consumption, and that demand for cars is relatively responsive to the cost of private car consumption: a $1 \%$ increase in the costs of private consumption of vehicles is likely to lead to a long-term decline in demand for car services of approximately 1.4\%.30

Any new policy measures that increase (decrease) the market UC of cars is therefore likely to set off a major additional (reduction in the existing) DWL due to the pre-existing distorted market. The intuition is recapped in Figure 6 which illustrates the arising new DWL in an already distorted market.

${ }^{30}$ Here we use the own-price elasticity of private consumption of vehicles ( $\mathrm{fcb}$ ) of $-1.42 \%$ used in the ADAMmodel, "ADAM-June14" version, Statistics Denmark. 


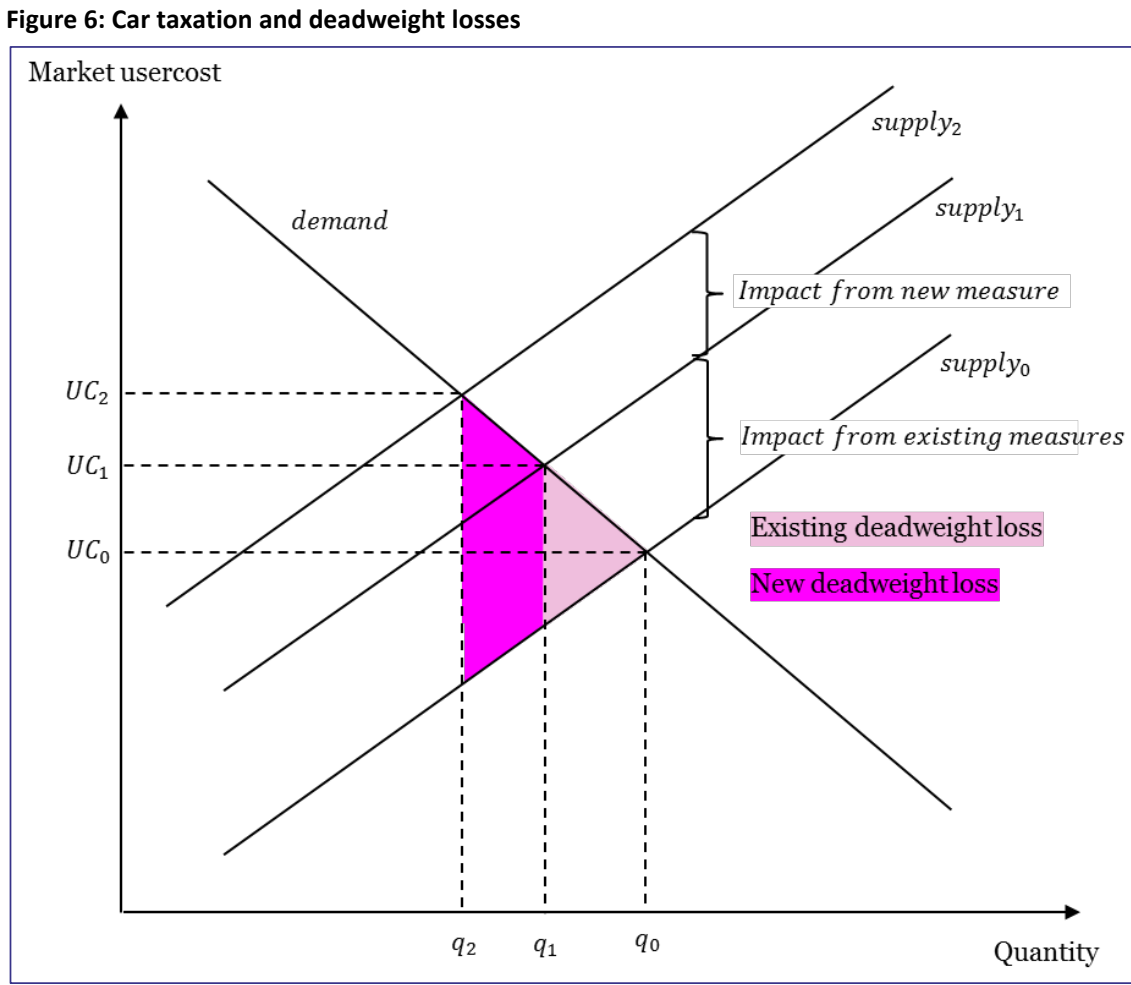

Source: Copenhagen Economics.

The specific calculation would have to take into account any substitution effects such as a switch to electric cars or diesel cars, etc. depending on the particular instrument considered. It is out of scope of this example to calculate a particular instrument's DWL and finally the shadow price. Here, we simply point out two important issues:

1. The market for cars is heaveliy distorted from the onset evident from the large difference between factor and market UC and a relatively high long-term own-pice elasticity of private car consumption.

2. Which is why any additional policy measure raising the market UC of cars is likely to offset a major additional DWL, contributing to a very high shadow price in the CB-analysis.

The implication of point 1 and 2 is that the shadow price of a higher car taxation (or any measure affecting the usercost of cars) is very high and that the environmental benefits obtained therefore have to be very 
substantial in order for the policy intervention to be economically profitable.

\subsubsection{Labour market distortion}

The very level of taxation of cars, also implies that the labour market implications of changing car taxation needs to be carefully considered bearing in mind also that cars are being used to transport between the home and their work place (pendling).

First round public revenue effects of reducing car taxation implies an immediate loss of revenue. However, second round effects might very well mean that reducing car taxation will have a high degree of "selffinancing".

We illustrate this important point starting with our above calculation where we found that the overall tax rate of car consumption (use and ownership) is approximately $73 \%$ measured as the ratio of market UC to factor UC. ${ }^{31}$

Households roughly split consumption expenditure between car consumption and other consumption with approximately $12 \%$ and $88 \%$, respectively. ${ }^{32}$ Based on the above calculation of UCs assume that for every DKK 1 of consumption expenditure other than cars at factor prices the consumer pays an additional DKK 0.25 in taxes (i.e. a total cost of DKK 1.25). Similarly, assume that for every DKK 1 of consumption expenditure on cars at factor prices the consumer pays an additional DKK 0.73 in taxes (i.e. a total cost of DKK 1.73).

Consider now the revenue implications of reducing the overall car consumption tax rate by 10 percentage points, i.e. from $73 \%$ to $63 \%$ when all other consumption is taxed at $25 \%$ of factor prices, cf. Table 7 .

\footnotetext{
$3157,500 / 33,300=1.73$.

32 Based on Statistics Denmark's consumption survey 2011-2013 we calculate this rough proxy. The share of consumption related to car is calculated as the sum of the categories: car, spare parts and other car accessories, fuels, repairs, other transport related services and annual owner's tax on car. This sum is divided by total consumption for the household.
} 
Table 7: Public revenue effects from reducing car taxation

\begin{tabular}{lrrr} 
& $\begin{array}{r}\text { Con- } \\
\text { sumption } \\
\text { excl. car }\end{array}$ & $\begin{array}{r}\text { Car con- } \\
\text { sumption }\end{array}$ & $\begin{array}{r}\text { Total } \\
\text { Change in } \\
\text { revenue }\end{array}$ \\
Before intervention & & & \\
Tax rate,\% & 0.25 & 0.73 & \\
Household expenditure, DKK & 88.00 & 12.00 & \\
Tax revenue, DKK & 22.00 & 8.76 & 30.76 \\
After intervention - "first round" & & & \\
Tax rate,\% & 0.25 & 0.63 & \\
Household expenditure, DKK & 88.00 & 12.00 & \\
Tax revenue, DKK & 22.00 & 7.56 & 29.56 \\
After intervention - "second round" & & & \\
Tax rate,\% & 0.25 & 0.63 & \\
Household expenditure, DKK & 86.32 & 13.68 & \\
Tax revenue, DKK & 21.58 & 8.62 & 30.20 \\
Long term own-price elasticity (private consumption of vehicles) & -1.40 & & \\
Total annual private consumptionsamlet, 2014 (nominal & 903.6 & & \\
prices), billionDKK & & & \\
\hline
\end{tabular}

Only considering first round effects, public revenue will fall by $1.2 \%$ points equivalent to approximately DKK 11 billion based on a total household private consumption expenditure of DKK 903.6 billion. ${ }^{33}$

Next, we need to consider that a decrease in the cost of car consumption increases demand for cars. More specifically, the long-term own-price elasticity of private consumption of vehicles is approximately $-1.4 \%$ implying that a decrease in the cost of car consumption of $10 \%$ will translate into an increase in private car consumption of $14 \%$

This means that the immediate loss of public revenue will be mitigated as the increase in car consumption expenditure is moved from the lower tax rate of $25 \%$ to the higher (post-intervention) overall car tax rate of $63 \%$ In our simple example, tax revenue now only falls by $0.56 \%$ points or a DKK 5 billion shortfall, i.e. DKK 6 billion less than when only considering first round effects. In other words, our simplified example suggest that reducing the overall tax rate of car consumption will be "self-financing" by roughly $50 \%$

This result is linked to a very basic fact: with a much higher taxation level on cars (linked to ownership or use of the car) than other consumer goods, any marginal reduction of tax rates has a very high degree of "self-financing". This is basically driven by the fact that more consumer spending will move towards consumption of car services

33 Private consumption 2014, nominal prices, Statistics Denmark. 
which also after the marginal reduction of rates will be taxed at a higher level than other consumption goods and services, here for simplicity by a simple uniform VAT rate of $25 \%$. $^{34}$

Now we need to find financing which compensates for the loss of revenue and keeps the income distribution constant. Cars are relativey sensitive to changes in income which requiries a mode of financing that is also dependent on income. We would hence suggest an increase in the VAT rate could do the trick of achieving a neutral ex-post distribution of incomes and a balanced budget. ${ }^{35}$

Now what happens with the labour market in this situation?

Labour market mobility should go up. The gains from getting a job will increase for workers depending on car transport, in turn leading to an increase in employment rates. Productivity should also increase as gains from getting a new better paying job requiring more travel time in a car is going up. The specific size of such effects are highly dependent on how the job market looks like in any given country and the importance of the car as a means of transport to work.

The new ex-post marginal tax rate on consumption is largely unchanged. This follows almost automatically from our financing. There is a twist in the sense that the reduction in the tax on car consumption before allowing for dynamic effects was larger than the increase in net VAT revenues. However, when adjusting for the increase in car's share of consumption, the marginal tax rate on consumption is unchanged.

Consequently, we do not expect any general labour supply effect from the twist in the structure of consumer taxes. It is true that the overall welfare is going up, that is the consumer welfare gain we saw above in the calculation of product market distortions. But, we do not expect any increases from changes in consumer welfare, this is essentially our argument that the long-run real wage elasticity is zero.

To put it differently, a product market shock making specific goods less or more expensive does not affect labour supply. It will increase the combined producer and consumer surplus from producing and consuming an unchanged level of that product. Furthermore, additional consumer welfare could be reached by shifting overall demand in the direction of the now less expensive product. But, we would certainly not expect any labour market effects from either general or specific positive productivity gains affecting the whole or parts of the economy.

34 The degree of "self-financing" is driven by two factors: the price elasticity of car use and the difference between the overall taxation of car use and other private consumption.

35 See Copenhagen Economics (2010). 


\subsection{Example 4: Waste management - higher recycling}

We have chosen this waste management example to illustrate a number of the complexities and necessary considerations present when a policy intervention as a side effect impact on government revenues through changes of the tax base while no taxes have been changed.

The example is a policy intervention aiming at achieving a higher recycling of waste. We will not decide on the specific intervention, as it could be designed in multiple ways and include several instruments from prohibition to price regulation, etc. Rather we chose to focus on the process of waste generation and recycling and the particularly interesting cost aspects related also to product and labour market impacts stemming from the fact that both the stream of public revenues and product markets are likely to be affected by an increased recycling of waste materials.

First, we describe the process of waste generation and recycling. Next, we briefly discuss the potential social benefits associated with higher recycling. Finally, we discuss in greater detail the different costs policymakers should pay attention to - including the impacts on product markets and the labour market - when setting up the CB-analysis.

\subsubsection{The process of waste generation and recycling}

Higher recycling of waste means that less waste will be used as burning material at incinerators and end up in landfills, cf. Figure 7, which illustrates the waste generation and recycling process. First, raw materials are refined and processed at plants to be sold as inputs in to the production of final consumer goods. Production and consumption of goods generate waste, which is basically handled in three ways: buried in landfills, recycled back as inputs in to production or burned at incinerators which produce energy for households and firms in the form of heat and electricity. 
Figure 7: Waste generation and recycling

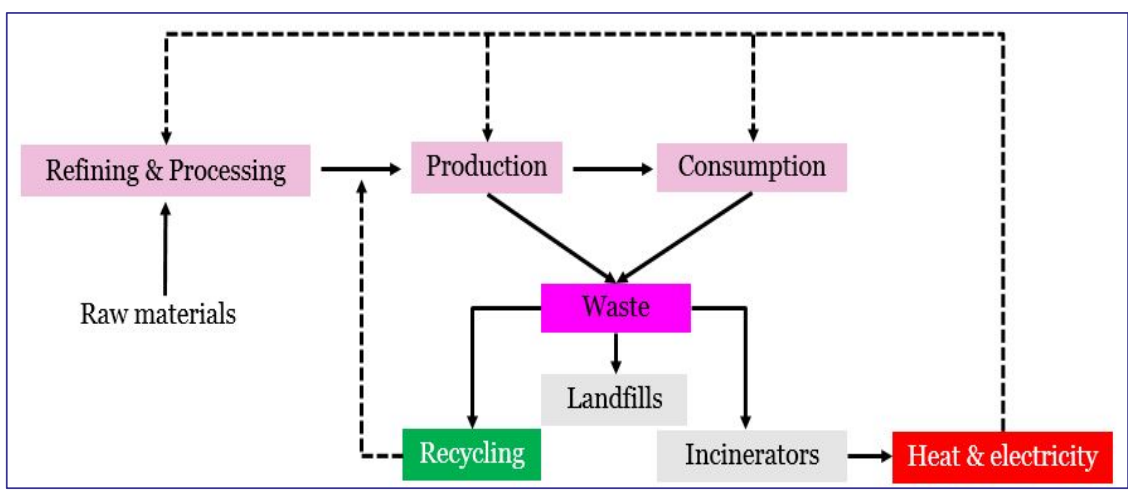

Source: Copenhagen Economics.

There are large differences in the treatment of waste across the EU28 and across the Nordic countries, cf. Figure 8. Of the approximately $481 \mathrm{~kg}$ of municipal waste generated per person in the EU28 in 2013, around 27\% was recycled. Sweden and Iceland have some of the highest recycling pct. ages and Iceland is a bottom producer of waste, whereas Danish citizens produce a lot of waste compared to other countries.

Figure 8: Municipal waste (kg./capita)

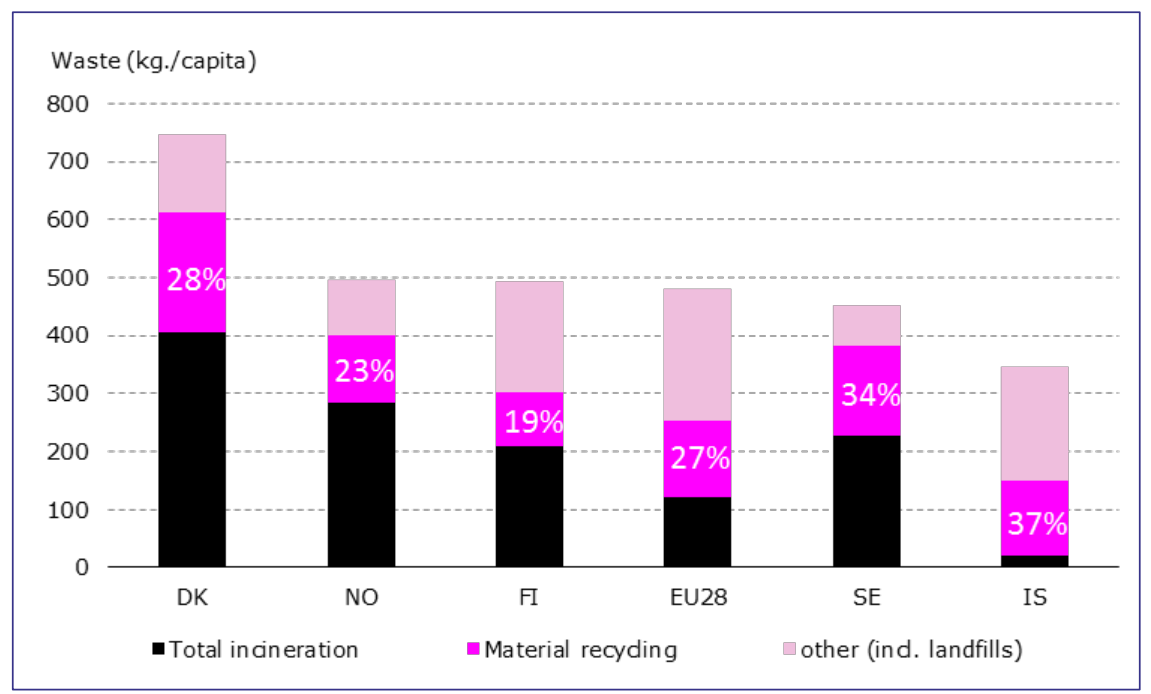

Note: The figure shows data for kilo of municipal waste generated per capita.

Source: EUROSTAT waste statistics (env_wasmun).

EU requires that the recycling pct. age of household waste for paper, glass, plastic and metal increases to a minimum of $50 \%$ by 2020 . 


\subsubsection{The benefits of recycling}

The benefits of a higher recycling will materialise in lower greenhouse gas emissions and a reduction in other types of pollutants.

When recycling is higher, energy used in the production of new materials will be saved. As an example, the manufacturing of drinking cans from recycled aluminium requires only about $4 \%$ of the energy necessary to produce the same aluminium cans starting from the raw material of bauxite ore. Consequently, when energy is saved so are emissions. For every 1 ton of aluminium production saved, approximately 10 tons of $\mathrm{CO}_{2}$ emissions are avoided. ${ }^{36}$ Added to these benefits are the avoided pollution to water and air associated with the production of new products from raw materials.

\subsubsection{The costs of recycling}

There are a number of direct and indirect costs that the policymaker should pay attention to when an intervention results in a higher recycling of waste:

- The net production cost of higher recycling - production costs.

- The potential environmental damages from policy-induced changes to the production and use of waste - environmental damages.

- The potential impact on public revenue and the associated impact on labour supply decisions - labour market distortion.

- The impact on product markets from a higher recycling of waste materials - product market distortion.

Below we will go through each type of cost listed above.

\section{Production costs}

A higher recycling pct. age will require an increased effort to collect, sort, process and market the recycled waste. This can partly be done at the source (firms and households) and partly at a later stage. The process will entail costs either in the form of additional time used for households and firms sorting waste and/or in the form of increased investments in labour and technology for the collection, post-source sorting and processing at designated plants/facilities. Disregarding the environmental and resource benefits associated with higher recycling,

${ }^{36} \mathrm{http}: / /$ www.popularmechanics.com/science/environment/a3757/4291576/ 
the cheapest way to get rid of waste is therefore usually - as done to a large extend - to bury the waste at landfills.

However, recycled waste will also create a revenue stream from its sales. In the US it is estimated that the average mix of recyclables collected from households have a value of USD 125 per ton when the recycled material is sold to manufactures. ${ }^{37}$ Whether revenues are likely to exceed costs depends on a number of factors, such as the specific waste material targeted, location (more waste can be collected for the same costs in cities - densily populated areas) and the development in technology, etc.

The important take away is that to the extent that costs will exceed revenues, firms and consumers will pick up the extra bill of the higher recycling efforts under the assumption of full cost-recovery where user fees are raised to match costs, cf. Figure 9 and Box 7 for illustration and example.

Figure 9: Costs recovery - Waste management facilities

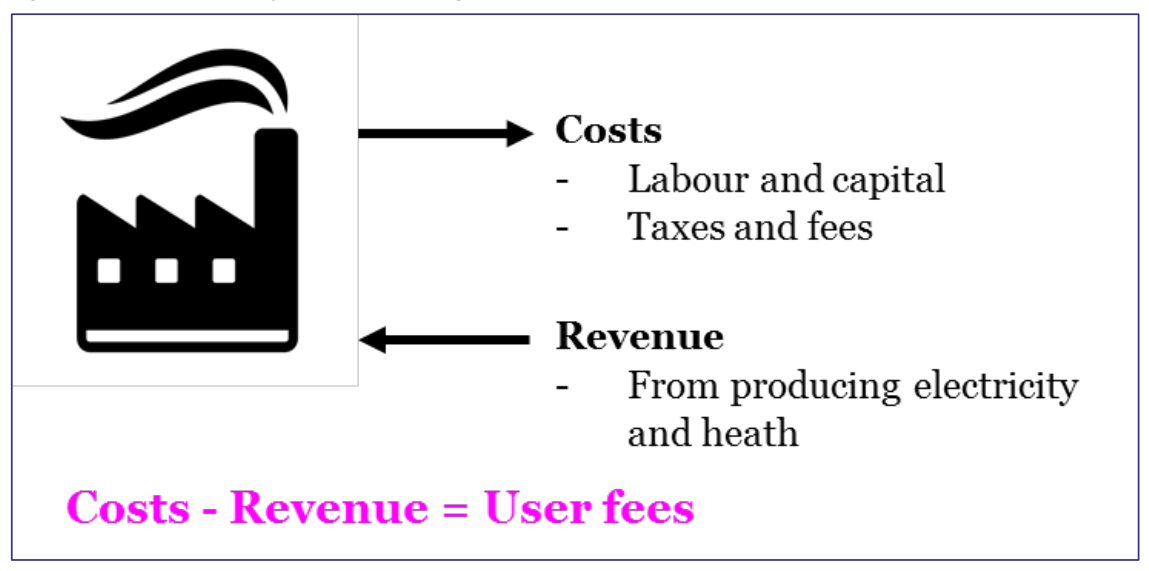

Source: Copenhagen Economics.

\section{Box 7: Example - Financing incinerators, Denmark}

Revenue for an incinerator consists of earning from the production of heat (approx. 50\%), electricity (approx. 20\%) and a waste charge, i.e. a user fee collected from households and firms.

Municipal incinerators are subject to a break-even principal, which means that incinerators can only charge fees to cover their net costs. This means that households and firms will pay a higher waste charge when the costs of an

${ }^{37}$ http://news.discovery.com/tech/is-recycling-worth-it.htm 
incinerator rises, which may be due to a period of over-capacity, low efficiency, etc. It also means, that households and firms are charged different fees depending on which incinerator they are assigned to by their local government.

For both households and firms, the waste charge consist of an administrative fee for handling of waste, and a component dependent on the volume of produced waste.

In addition, the incinerators are subject to the principal of equal treatment, which means that all consumers who are obligated to delivering waste to a specific incinerator, has to be charged according to equal and objective criteria. Firms are allowed to export their waste to a foreign incinerator, although not to a different domestic incinerator than the one directed to them by their local government.

Source: BEATE (2013), KL (2011).

\section{Environmental damages}

As already argued, one of the core benefits of a higher recycling is the fall in emissions and pollution from using less energy in the production of new products from raw materials.

However, it is important that policymakers assess the impact on these externalities from the necessary substitution of waste for other burning materials at incinerators when more waste is recycled.

To the extent that waste is replaced with e.g. coal this is likely to increase the externality costs at the incinerators. These added damages should be subtracted from the intended avoided damages obtained through energy savings.

\section{Product market costs}

There are two issues that we need to consider regarding the impact on product markets:

- The impact on the market for waste handling services.

- The impact on the product markets that use recycled waste in production: glass, metals, plastic, wood, paper, etc.

First, let us consider the market for waste handling services. More specifically, a policy intervention that increases the pct. of recycled waste, but at a higher marginal cost than earlier. The extra costs are recovered by waste management facilities through higher waste charges 
levied on wasters, i.e. consumers and firms. The consequence is that the new "technology" (higher recycling) makes waste handling services more expensive than the old "technology" (deposit at landfill) resulting in a traditional DWL on the market for waste handling services.

Next, let us consider the potential impact on the product markets that use recycled waste in production. If the market from the onset is undistorted and competitive, we should not expect any product market impact from a higher recycling. Only to the extend that inputs into production from recycled materials are cheaper than inputs from virgin materials (still not considering the externality effects, i.e. the benefitside) can there be a positive product market distortion - a consumer surplus. However, this naturally begs the question: Why was this not done by the market in the first place then?

\section{Labour market distortions}

Here we need to consider if and how the public budget is impacted by the new policy intervention.

- Any net negative impact on the public budget will require a tax financing need (balanced budget assumption) and thus set off a labour market distortion.

Throughout the process of waste handling, a number of taxes are levied on the different facilities such as landfills and incinerators. A change to the process of waste handling in the form of higher recycling is therefore likely to affect the public budget depending on the size and structure of the different taxes.

If the result is a net negative impact on the public budget, government will have to raise taxes to keep a balanced budget. The standard assumption in guidelines is to raise income taxaion and include on the cost-side the arising DWL on the labor market, which is estimated at between $20 \%$ and $30 \%$ of the net financing need, cf. the MCPF discussion in section 1.2.

To illustrate the potential complexities of estimating the impact on the public budget from a higher recycling we again use Denmark as an example. Denmark has a number of taxes in place. A deposit-tax that landfills pay per ton of waste deposited and as the only Nordic country an incineration-tax positively dependent on the $\mathrm{CO}_{2}, \mathrm{NOx}$ and $\mathrm{SO}_{2}$ emission content per ton.

Everything else equal a higher pct. of recycling will result in less waste being deposited at landfills and less waste being burned at 
incinerators in the production of heat and energy. To meet heating and energy demands waste will have to be replaced partly with coal where the incineration-tax is higher due to higher emission content.

So it is up to the policymaker to disentangle the impact on the public budget from the different taxes in place, e.g.:

- The loss of tax revenue from less waste being deposited at landfills.

- Plus the loss in revenue from less incineration of waste.

- Minus the increase in revenue from a higher use of coal at incinerators.

As stated in guidelines for DK, NO and SE the potential identified net public financing need should be raised with the arising DWL in the labour market and added to the cost-side of the analysis. 



\section{References}

\section{Overall references}

Ackerman, F., and E. Stanton (2010). The social cost of carbon - A report for the Economics for Equity and the Environment Network, April 2010.

BEATE (2012). Benchmarking af affaldssektoren 2013 - Forbrænding, Dansk Affaldsforening, DI og Dansk Energi, 2013.

Christian Ege (2010). Traffic related taxes in the 5 Nordic countries, Project for the Nordic Council of Ministers, T\&E seminar, 19 March 2010.

Concito (2014). Klimavenlig transportbeskatning, February 2014.

Copenhagen Economics (2010). Taxation Papaers, Company Car Taxation, working paper prepared for DG Taxud, No.22, 2010.

Copenhagen Economics (2012). En grøn omlægning af bilbeskatning, Dansk Elbilalliance, 6. juli 2012.

Copenhagen Economics (2014). Welfare costs and marginal costs of public funds: integration in government policy appraisal, Discussion Note, Copenhagen Economics.

Crawford et al. (2008a). Environmental taxes, March 2008.

Crawford et al. (2008b). Value-Added tax and excises, March 2008 Louis Kaplow (1998), A Note on the Optimal Supply of Public Goods and the Distortionary Cost of Taxation.

Duer, H., Rosenhagen, C. and P. Ø. Ritnagel (2011). A comparative analysis of taxes and $\mathrm{CO}_{2}$ emissions from passenger cars in the Nordic countries, TemaNord 2011:523.

DØRS (2013). Energi- og klimapolitik. Bilbeskatning, ulykker og miljø affald, De Økonomiske Råd, 2013.

Emmanuel Saez (2009). The Elasticity of Taxable Income with Respect to Marginal Tax Rates: A Critical Review.

ENS (2014). Danmarks Energi- og Klimafremskrivning 2014, Energistyrelsen, 2014.

IWG (2013). Technical support document - Technical update of the social cost of carbon for regulatory impact analysis, Interagency Working Group on Social Costs of Carbon, United States Government, May 2013.

Kimball et al. (2010). Labor Supply: Are the Income and Substitution Effects Both Large or Both Small?

KL og Reno Sam (2011). Kommunernes fremtidige rolle vedrørende forbrænding af affald, Analyse af konsekvenser for commune rog kommunale anlæg ved konkurrenceudsættelse, herunder pligt til udbud af husholdningsaffald.

Louis Kaplow (2011). An Optimal Tax System. Discussion Paper No. 701. http://dx.doi.org/10.1111/j.1475-5890.2011.00144.x

Louis Kaplow (2012). Optimal control of externalities in the presence of income taxation, International Economic Review, Vol. 53, No. 2, May 2012.

http://dx.doi.org/

10.1111/j.1468-2354.2012.00689.x 
Nordhaus, W. (2011). Estimates of the social cost of carbon: Background and results from the RICE-2011 model, Cowles Foundation discussion paper, October 2011.

Oates, W. (1993). Pollution charges as a source of public revenue, Economic progress and environmental concerns, Berlin: Springer-Verlag, 1993.

Oates, W., \& I. Parry (2000). Policy Analysis in the presence of Distorting Taxes, Journal of Policy Analysis and Management, Vol. 19, No. 4, 2000.

OECD (2013). Taxing Energy Use, A graphical Analysis, OECD 2013.

Pearce, D. (1991). The role of carbon taxes in adjusting to global warming, Economic journal 101, 938-948. http://dx.doi.org/10.2307/2233865

Repetto, R. Dower, R., Jenkins, R., \& Geoghegan, J. (1992). Green fees: How a tax shift can work for the environment and the economy. World resource institute, 1992.

Richard Rogerson (2008). Market Work, Home Work and Taxes: A Cross Country Analysis. Working Paper 14400.

Ricardo-AEA (2014). Update of the Handbook on External Costs of Transport, European Commission, DG MOVE, 8th January 2014.

Slemrod, J. and C. Gillitzer (2013). Insights from a tax systems perspective, October 2013.

Stiglitz, J. E. (2000). Economics of the Public Sector. London: Norton, Chapter 11: Cost Benefit Analysis.

Sørensen et.al. (1996). Subsidising Consumer Services: Effects on Employment, welfare and the Informal Economy, Institute for Fiscal Studies, 1999.

Sørensen, P. B. (2010). Swedish Tax Policy: Recent Trends and Future Challenges, Peter Birch Sørensen, Regeringskansliet, Ministry of Finance, 2010.

Watkiss, P. (2006). The social cost of carbon: Use of the values in Policy, OECD, July 2006.

\section{References - Nordic Guidelines}

\section{Denmark}

Energistyrelsen (2013). Beregningsmetode til samfundsøkonomiske omkostninger ved virkemidler i klimaplan.

Finansministeriet (1999). Vejledning i udarbejdelse af samfundsøkonomiske konsekvensvurderinger.

Miljøministeriet (2010). Samfundsøkonomisk vurdering af miljøprojekter, Miljøministeriet 2010.

Miljøstyrelsen (2013). Virkemiddelkatalog for NOX, PM2.5, NMVOC og NH3.

Transportministeriet (2015). Manual for samfundsøkonomisk analyse på transportområdet.

\section{Norway}

Concept (2013). Bruk av karbonpriser i praktiske samfunnsøkonomiske analyser.

Direktoratet for økonomistyring (2014). Veileder i samfunnsøkonomiske analyser.

Finansdepartementet (2014). Rundskriv $R$ - Prinsipper og krav ved utarbeidelse av samfunnsøkonomiske analyser mv.

Kommunal- og moderniseringsdepartementet (2005). Instructions for Official Studies and Reports.

NOU (2012). Samfunnsøkonomiske analyser. 
Senter for statlig økonomistyring (2008). Omstilling av statlige virksomheder Veileder i beregning av samfunnsøkonomiske gevinster og kostnader.

\section{Finland}

Justitieministeriet (2008). Konsekvensbedömning av Lagförslag - Anvisningar.

\section{Sweden}

Förordning (2007-1244) om konsekvensutretning vid regelgivning.

Konjunkturinstitutet (2009). Klimatanpassning i Sverige: Samhällsekonomiska värderingar av hälsoeffekter.

Konjunkturinstitutet (2012). Mjuklänkning mellan EMEC och TIMES-Sweden - en metod för att förbättra energipolitiska underlag.

Kriström, B. og Bergman, M. B. (2014). Samhällsekonomiska analyser av miljöprojekt: en vägledning.

Naturvårdsverket (2003). Konsekvensanalys steg för steg: Handledning $i$ samhällsekonomisk konsekvensanalys för Naturvårdsverket.

Naturvårdsverket (2004). Ekonomiska konsekvensanalyser i myndigheternas miljöarbete. Naturvårdsverket (2008a). Samhällsekonomisk konsekvensanalys av miljöåtgärder.

Naturvårdsverket (2008b). Kostnads-nyttoanalys som verktyg for prioritering af efterbehandlingsinsatser: Metodutveckling och exempel på tillämpning.

Naturvårdsverket (2014). En kartläggning och kategorisering av samhällsekonomiske analyser inom miljömålsområdet.

Riksantikvarieämbetet (2008). Metodhandledning i samhällsekonomisk konsekvensanaly. Trafikverket (2014). ASEK 5.1 - Samhällsekonomiska principer och kalkylvärden för transportsektorn.

\section{United Kingdom}

Department for Environment, Food and Rural Affairs (2007). An Introductory guide to valuing ecosystem services.

Department of Energy \& Climate Change (2014). Valuation of energy use and greenhouse gas (GHG) emissions.

HM Treasury (2003). The Green Book - Appraisal and Evaluation in Central Government.

HM Treasury (2009). Accounting for the Effects of Climate Change.

HM Treasury (2012). Accounting for environmental impacts.

HM Treasury (2013a). Public Sector Business Cases Using the Five Case Model.

HM Treasury (2013b). Valuing impacts on air quality.

HM treasury (2014) Supplementary Appraisal Guidance. 



\title{
Danish Summary
}

\author{
Studiets afgrænsning
}

De nordiske lande har ambitiøse mål til fremme af miljøpolitiske målsætninger på en bred vifte af områder.

Til sikring af, at policy tiltagene er omkostningseffektive anvender alle lande cost-benefit analyser. Målet er at støtte en politisk beslutningsproces, hvor ethvert givet mål nås til de laveste omkostninger, og hvor, ideelt set, de marginale omkostninger ved opnåelsen af målet er lig de marginale gevinster. Dette kræver per definition et sæt af principper og en praksis som definerer hvordan man bør beregne omkostninger og gevinster.

Formålet med denne rapport er at adressere omkostningssiden af cost-benefit-analysen med fokus på de to vigtigste forvridninger som miljøpolitiske tiltag kan give anledning til, og som cost-benefit-analysen kan hjælpe med at kvantificere.

Den første type forvridning er forvridninger der afstedkommer på produktmarkedet. Miljømæssige tiltag vil næsten per definition skabe en kile mellem omkostningerne ved at producere de produkter som forbrugerne vil købe og markedsprisen de skal betale. Dette skaber en velfærdstab fordi forbrugerne nu køber mindre af produktet til en højere pris end de faktiske produktionsomkostninger. Dette er det såkaldte forbrugertab.

Den anden er den mulige forvridning der kan opstå på arbejdsmarkedet. Vi tager det som givet, at formålet med miljøpolitikken er miljøet. Men hvad kunne bivirkningerne være på arbejdsmarkedet? Politiske indgreb vil være tilbøjelige til at reducere både produktivitet og realløn ved at gøre forbrugsvarer dyrere: bedre miljøpraksis kan fx kræve dyrere behandling af affald eller investeringer i energieffektivitet som ikke kompenseres fuldt ud ved lavere nettoomkostninger for forbrugerne. Politikkerne kan også direkte eller indirekte påvirke de offentlige finanser: nye miljøafgifter øger indtægterne, der kan bruges til at reducere de direkte skatter på arbejdsindkomst. Hvordan påvirker en reduceret realløn og sådanne drejninger i skattestrukturen arbejdsudbuddet? 
I rapporten præsenteres nogle centrale erfaringer fra best-practices med hensyn til evalueringer og beregninger af de to mulige forvridninger, og de faktiske praksisser formuleret i eksisterende nordiske vejledninger sammenlignes.

\section{Hovedkonklusioner}

Den normale praksis ved beregning af produktmarkedsforvridninger i empiriske studier er relativt ligetil og baseret på det såkaldte forbrugertabs-princip. Det er nødvendigt at definere det reelle underliggende forbrugermarked som ultimativt påvirkes af det miljømæssige tiltag. Eksempelvis vil en foranstaltning, der forbyder visse giftige stoffer anvendt $i$ produktionsprocessen $i$ en fremstillingsvirksomhed i sidste ende føre til en stigning i prisen på produkter der anvender stoffet. Dette fører til to typer af tab: de højere produktionsomkostninger omsættes en-til-en til et forbrugertab. Så forbrugere vil også reducere efterspørgslen som priserne stiger. På margen betaler forbrugerne mere for, og bruger mindre af, de underliggende varer end hvad det koster at producere dem på den billigst mulige måde. Så vi er nødt til at identificere det berørte marked, den endelige direkte stigning i produktionsomkostninger og ændringen $\mathrm{i}$ forbrugernes efterspørgsel.

En afgift på en forurenende aktivitet virker på en lignende, men ikke helt samme, måde. Den højere skat vil udmønte sig i en højere pris for forbrugerne og tilskynde dem til at bruge mindre. Det er et tab for samfundet, fordi forbrugernes betalingsvillighed er højere end varens produktionsomkostninger.

Det er vigtigt i udførslen af disse beregninger at forstå, at det ekstra forbrugstab/gevinst fra ethvert nyt politisk tiltag er yderst afhængig af det eksisterende forbrugstab foranlediget af bestanden af eksisterende politikker, som påvirker den regulerede aktivitet.

Et praktisk eksempel fra rapporten illustrerer denne pointe. Beskatningen af forbrug af bil (bilservice) er i alle de nordiske lande høj og skaber store forvridningstab når der ses bort fra de miljømæssige mål skatterne er tiltænkt at levere på. Dette indebærer, at forbrugernes betalingsvillighed for bilservices (ejerskab og brug af bil) allerede langt overstiger produktionsomkostningerne. Når der tilføjes endnu et lag af beskatning, vil forbrugerens tab være meget større end hvis bilservice i udgangspunktet var beskattet på samme niveau som andre varer. 
Ved hjælp af best-practices, bør beregninger af arbejdsmarkedseffekter fra produktmarkeds-interventioner, såsom miljøpolitik, bygge på fire centrale arbejdsmarkeds og public finance principper:

- Fire dimensioner af arbejdsudbud: Præciser, at arbejdsudbudsbeslutninger ikke kun handler om at vælge mellem fritid og betalt arbejde. Lige så vigtigt er to andre "tidsanvendelser" som ikke beskattes, nemlig gør-det-selv arbejde og sort arbejde.

- Budgetbalance: Se bort fra effekter af miljøpolitiske tiltag, der implicit antager at statens langsigtede gældsposition påvirkes.

- Uændret indkomstfordeling: Formålet med miljøpolitik er at opnå miljømæssige mål og ikke at ændre indkomstfordelingen. I kombination med princippet om budgetbalance implicerer dette at virkninger på arbejdsmarkedet bør være baseret på princippet om at nettobudgettet og indkomstfordelingen er uændret.

- En langsigtet realløns-elasticitet for arbejdsudbuddet på nul: Miljøpolitikker der påvirker den samlede produktivitet i økonomien, f.eks "kommando og kontrol politikker", som gør produktionen dyrere, vil som en første approksimation ikke påvirke arbejdsudbuddet på lang sigt (men kan indebære transitionsomkostninger i form af tabte jobs i den berørte industri, som skal genskabes andetsteds).

Resultatet af disse principper er først og fremmest følgende:

Ingen dobbelt-dividende-effekt generelt: højere indtægter fra miljøskatter skal "genbruges" på en måde så indkomstfordelingen holdes uændret. Dette vil generelt betyde, at marginalbeskatningen af arbejde og dermed incitament til at undgå beskattet arbejde forbliver uændret. Vi diskuterer varianter af dette princip i rapporten.

Politikker, der indebærer en nettobyrde for de offentlige finanser, såsom tilskud til nye og grønnere teknologier skal finansieres ved højere skattesatser. Selv hvis skattestigningen er udformet således at indkomstfordelingen holdes uændret, vil den samlede effekt af billigere teknologi og højere skatter bevirke at den højere skattesats tilskynder til at skifte tidsforbrug fra den formelle (beskattede) sektor til ikkebeskattede aktiviteter. Her er det taget som givet at adgang til fordelene ved den nye teknologi ikke er strengt afhængig af antallet af arbejdstimer eller størrelsen af indkomstbeskatningen.

Til gengæld betyder det, at den nye politik har konsekvenser for arbejdsmarkedet i form af et reduceret udbud af arbejdskraft, selv i tilfælde hvor den fælles effekt af støtte til teknologi og højere skat holder 
reallønnen uændret. Dette kaldes ofte "the marginal cost of public funds" (MCPF) effekten.

\section{Nuværende praksis i de nordiske lande}

Klare retningslinjer for beregninger af produktmarkeds- og arbejdsmarkedsforvridninger er generelt relativt sparsomme i de nordiske lande.

Den mest præcise opgørelse indarbejdet i de danske, norske og svenske vejledninger er begrebet "Marginal Cost of Public Funds" relateret til tiltag som netto øger statens finansieringsbehov indhentet igennem indkomstbeskatning som anbefalet i standard cost-benefit analyser (stort set på samme måde med afvigelser diskuteret i rapporten).

På trods af at begrebet om forbrugstab/gevinster er temmelig standard i økonomiske lærebøger, og forholdsvis enkel at beregne når data eksisterer, findes der kun få generelle anbefalinger til hvordan forbrugstab/gevinster beregnes i retningslinjerne. Ej heller har vi set brugen af sådanne estimater i faktiske anvendte cost-benefit-analyser.

\section{Anbefalinger}

Manglen på grundige tilgange til beregning af produkt- og arbejdsmarkedseffekter i miljøpolitikken kan reducere kvaliteten af den politiske beslutningsproces. Det kan naturligvis føre til alt for optimistiske vurderinger af nettogevinsterne af politiske tiltag, når vigtige typer af omkostninger ikke medregnes. Men lige så vigtigt kan det påvirke rangeringen af et givet sæt af tiltag der alle sigter efter at opnå det samme mål. Tiltagene kan alle levere på det miljømæssige mål, men adskiller sig væsentligt på deres virkninger på arbejds- og produktmarkederne, hvilket bør være en del af beslutningsprocessen.

Vi anbefaler derfor, at de nordiske lande enten individuelt eller kollektivt etablerer nogle fælles retningslinjer for hvordan sådanne effekter medreges i deres nationale policy-design process. Omkostningerne forbundet med at indarbejde sådanne virkninger i costbenefit-analyserne, bør ikke overdrives. Vigtige input til beregninger, såsom virkningerne af tiltaget på den forurenende aktivitet, vigtige produktmarkeder og de offentlige finanser er typisk målt allerede. 


\section{Appendix A}

\section{Analytical example 1 - removing the PSO-charge}

The price of electricity (and the tax contributions) used in the calculation is based on a simple average of detailed price data published by the Danish Energy Regulators Authority (DERA) for households and large and small firms, cf. Table A.1.

Table A1: Price and taxes - electricity

\begin{tabular}{|c|c|c|c|}
\hline & Households & Small firms & Large firms \\
\hline Network subscription & 13.1 & 2.2 & 0.1 \\
\hline Network tariff & 48.7 & 47.7 & 32.5 \\
\hline thereof PSO-tax & 21.1 & 21.1 & 21.1 \\
\hline Total network payment & 61.8 & 49.9 & 32.6 \\
\hline Pure electricity price - subscription & 2.7 & 0.1 & 0 \\
\hline Pure electricity price & 31.2 & 31.2 & 20.5 \\
\hline Total price excl. Taxes and VAT & 95.7 & 81.2 & 53.1 \\
\hline Taxes and VAT & 133.7 & 0.4 & 0.4 \\
\hline thereof electricity-tax & 87.8 & 0.4 & 0.4 \\
\hline thereof VAT & 45.9 & 0 & 0 \\
\hline Total price incl. taxes and VAT & 229.4 & 81.6 & 53.5 \\
\hline
\end{tabular}

Source: Copenhagen Economics based on DERA. 
Besides the price of electricity, we need consumption (incl. elasticities), quota-price and emission data, cf. Table A.2.

\begin{tabular}{|c|c|c|}
\hline Variable & Value & Description and source \\
\hline Consumption (Gwh) & 34,619 & 2014, Energinet \\
\hline Consumer elasticity (pct.) & $0.33^{1}$ & DØRS (2011) \\
\hline $\mathrm{CO}_{2}$ quota-price (2020) (DKK/ton) & 78.9 & $\begin{array}{l}\text { DEA background note C: Produktion af EL og Fjernvarme, } \\
\text { Danmarks Energi- og Klimafremskrivning } 2014\end{array}$ \\
\hline $\begin{array}{l}\mathrm{CO}_{2} \text { emission from energy- } \\
\text { consumption (g/Kwh) }\end{array}$ & 150 & Danmarks energi- og klimafinansiering 2014 \\
\hline $\begin{array}{l}\text { Impact on electricity price ( } \varnothing \mathrm{re} / \mathrm{Kwh}) \\
\text { from a quota-price of DKK } 100 / \text { tonne }\end{array}$ & 6 & 2007, Ministry of taxation based on DEA \\
\hline
\end{tabular}

Note: $\quad{ }^{1}$ The elasticity is the average for "industry" (0.46) and private consumption (0.20). An elasticity of 0.33 means that electricity consumption will fall by $0.33 \%$ for a $1 \%$ increase in the price of electricity.

Source: Sources stated in the table.

The following assumptions have been applied:

- A simple average over households and firms (large and small) is used for prices and taxes based on data stated in Table A.1. This results in an actual average price of DKK 1.215/Kwh, thereof an electricity-tax of approximately DKK $0.030 /$ Kwh, a PSO-tax of DKK $0.211 /$ Kwh and based on the relationship between quota-price and price of electricity a quota-tax of DKK $0.047 /$ Kwh for a quota-price of DKK 78.9/ton. Then, four prices can be calculated under the assumption of unchanged VAT-payments (DKK $0.153 /$ Kwh) and network-costs (network-taxes excl. PSO-tax of DKK 0.22/Kwh and network-subscription of DKK 0.05/Kwh):

- Price incl. quota-, electricity- and PSO-tax = DKK 1.216/Kwh

- Price incl. quota- and electricity-tax = DKK 1.005/Kwh

- Pris incl. quota-tax $=$ DKK 0.705 $/$ Kwh

- Price excl. taxes $=65.8$

- The price elasticity of electricity demand is $0.33 \%^{38}$ and a linear approximation is used in the calculations. 
- Electricity consumption is $34,619 \mathrm{Gwh}$ based on data from Energinet for total electricity consumption in 2014.

- We disregard potential impacts on production surplus by assuming a horizontal supply curve. It can be noted that this assumption will only lower the net benefit of removing the PSO-tax. 
Ved Stranden 18

DK-1061 Copenhagen K

www.norden.org

\section{Environmental policy analysis}

This report discusses how policymakers should deal with economic distortions on the cost-side of cost-benefit analysis in the area of environmental policies, and assesses the existing Nordic guideline recommendations. The two types of economic distortions are distortions to product markets, which are almost by definition tied to environmental policy interventions, and distortions to labour supply decisions. Drawing on best practices from the literature, we formulate a number of key principles useful for assessing the impact on labour supply decisions and welfare on product markets from policy interventions. Four analytical examples are included to illustrate the importance of these principles for the correct quantification of distortionary impacts, especially the importance of taking into account pre-existing policy induced distortions.

TemaNord 2015:576

ISBN 978-92-893-4393-0 (PRINT)

ISBN 978-92-893-4391-6 (PDF)

ISBN 978-92-893-4390-9 (EPUB)

ISSN 0908-6692 